TA

435

P2

|||||||||||||||||||||||||||||||||||||||||

\$B ?b lab 


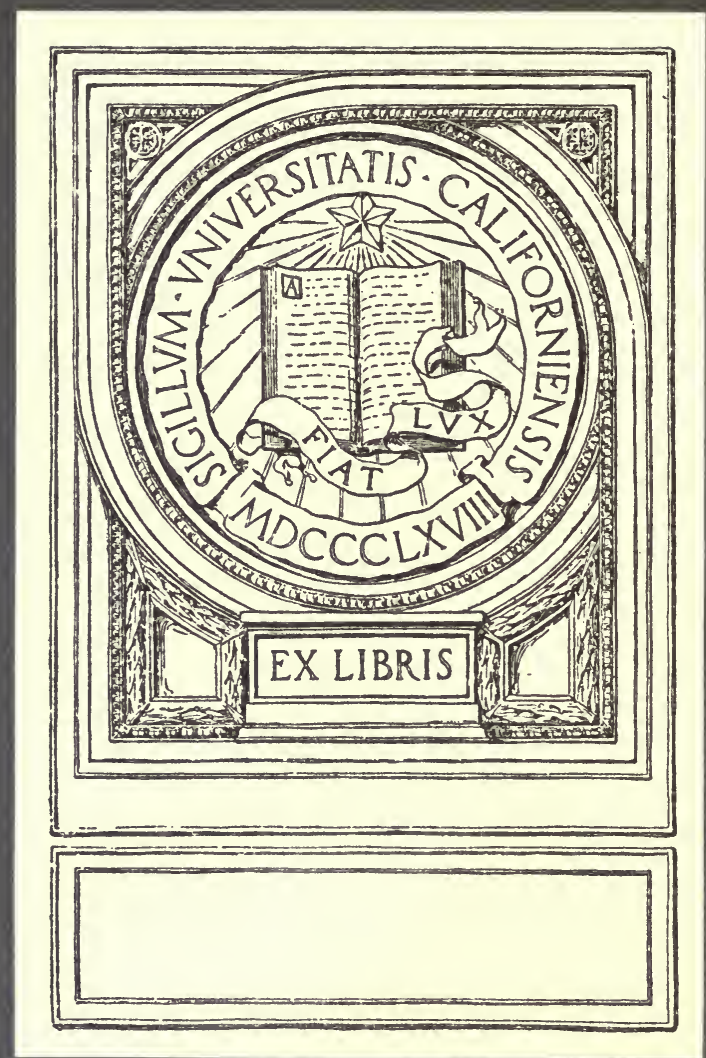


ANNALS OF THE NEW YORK ACADEMY OF SCIENCES

Vol. XXII, pp. 161-224

Editor, Edmund Öts Hovey

\section{METAMORPHISM OF PORTLAND CEMENT}

BY

Albert B. Pacini

NEW YORK

PUBLISHED BY THE ACADEMY

10 September, 1912 


\section{THE NEW YORK ACADEMY OF SCIENCES}

(Lyceum of Natural History, 1817-1876)

\section{OFFICERS, 1912}

President-Emerson McMillin, 40 Wall Street

Vice-Presidents-J. Edmund Woodman, Frederic A. Lucas,

Charles Lane Poor, R. S. Woodworth

Corresponding Secretary-Henry E. Crampton, American Museum

Recording Secretary-Edmund Otis Hovey, American Museum

Treasurer-HenRy L. DoHeRTy, 60 Wall Street

Librarian-RALPH W. Tower, American Museum

Editor-Edmund Otis Hover, American Museum

\section{SECTION OF GEOLOGY AND MINERALOGY}

Chairman-J. E. Woodman, N. Y. University

Secretary-Charles P. BerkeY Columbia University

\section{SECTION OF RIOLOGY}

Chairman-Frederic A. Lucas, American Museum

Secretary-William K. Gregory, American Museum

SECTION OF ASTRONOMY, PHYSICS AND CHEMISTRY

Chairman-Charles Lane Poor, Columbia Utiversity

Secretary-F. M. Pedersen, College of the City of New York

SECTION OF ANTHROPOLOGY AND PSYCHOLOGY

Chairman-R. S. Woopw-oRTH, Columbia University

Secretary-Frederic LyMaN WeLLS, Columbia University

The sessions of the Academy are held on Monday evenings at 8:15 o'clock from October to May, inclusive, at the American Museum of Natural History, 7\%th Street and Central Park, West. 
[Axxals N. Y. Acad. Sci., Vol. XXII, 11). 161-224. 10 September, 1912]

\title{
METAMORPHISM OF PORTLAND CEMENT ${ }^{1}$
}

\author{
By Albert B. Pacini \\ (Read before the Academy, Part I on S January, 1912; Part II, 1 April, \\ 1912)
}

CONTENTS

PART I

Page

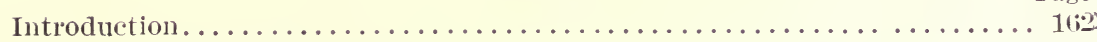

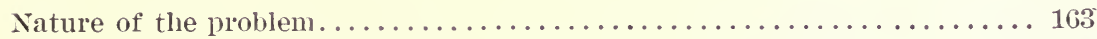

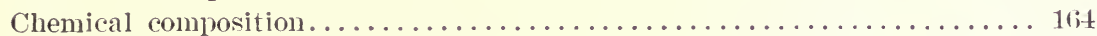

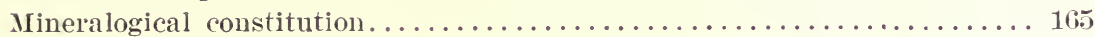

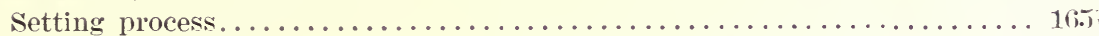

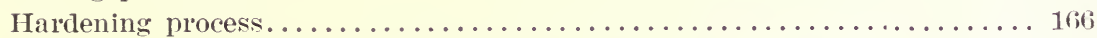

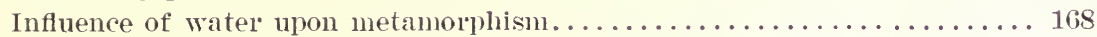

Temperature of the water at first added................. 162

Temperature of the water that may subsequently come into contact

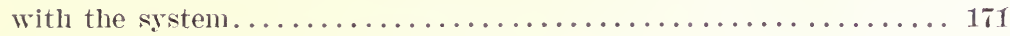

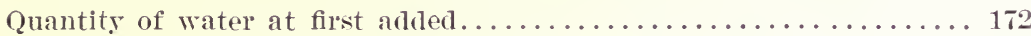

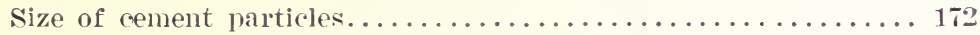

Laitance.................................... 17:?

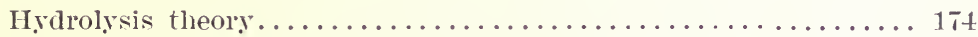

Mechanical agitation when water is added.................. 17

Total quantity of water at first added.................... 175

Quantity of water that may subsequently come into contact with the

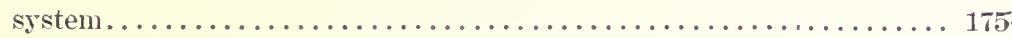

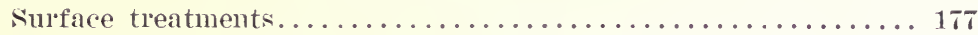

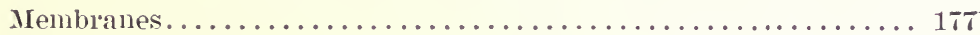

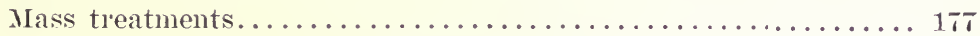

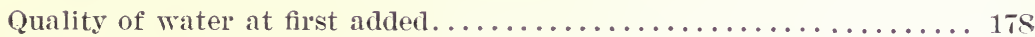

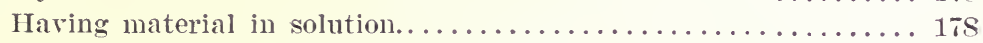

Quality of water that may subsequently come into contact with the

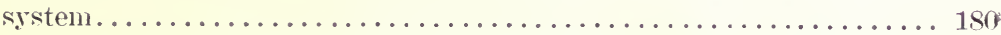

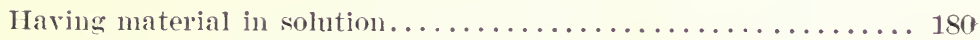

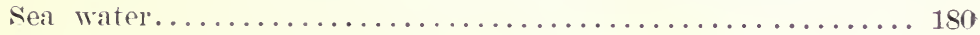

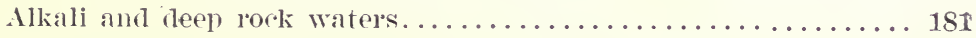

Having material in suspension.......................

${ }^{1}$ A thesis submitted in candidacy for the degree of Ioctor of Science at New York University, 1912.

Acknowledgments are due to Prof. J. Edmund Woodman and Mr. Raymond B. Earle, of the Department of Geology, New York Lniversity, and to Engineer Inspector Ernst Jonson, Board of Water Supply, City of New York, for valuable suggestions made during the preparation of this paper: also to Mr. Fred H. Parsons, Assistant Engineer, and Messrs. James E. Jay, Charles M. Montgomery and Charles E. Price. Inspectors, of the Board of Water supply Laboratory, for material assistance during the experimental work. 
to the petrologist and hydrologist; and this paper is an attempt to treat cement as a rock, differing from other rocks only in being artificial, but subject to the same internal and external influences as other components of the earth's crust.

A training in geophysics and geochemistry is, perhaps, the most valuable asset in surveying the field of Portland cement. If no other end is achieved by the following pages, the mere representation of the question as a problem in applied petrology will, it is hoped, help future investigators in a more systematic inquiry.

Part I of this paper is deroted to a necessarily brief review of the present status of the subject, and no attempt is made to discuss data quantitatively. Experimental results in elaboration of the various points discussed are presented in Part II.

The experiments described in Part II were made at the laboratory of the New York Board of Water Supply by the writer, and in part by his associates, in the course of the investigations of the Board. The most modern and complete equipment was arailable, thanks to the prudent foresight of the gentlemen at the head of this great engineering enterprise. The data are reproduced by permission from the periodical bulletins of the Inspection dirision and from the annual report of the Board for 1911.

\section{Natcre of the Problex}

Portland cement is a finely ground artificial rock, whose essential constituents are silica, alumina and lime. In it are found a number of component minerals recognizable by definite optical properties, but the individual constitution of which is not yet clear. 'The percentages of these minerals vary somewhat according to the method of manufacture and the purity of the raw materials, but there is, on the whole, a fairly stable proportion in a series of normal cements.

The method of manufacture of Portland cement will not be discussed here further than to state that it consists essentially of the calcination of a mixture of calcareous and argillaceous rocks at high temperatures. Lsually, about 2 per cent of gypsum or of plaster of Paris is afterwards adiled to retard the set. By varying the proportion of these rocks, the temperature and duration of calcination, the fineness of grinding, and also by the addition of foreign substances products are obtained having a wide range of hydraulic properties.

The hydraulic properties are setting and hardening. Setting is the attainment of rigidity by the plastic mixture of cement and water and begins inmediately after mixing, requiring several hours for completion. 
Hardening is the progressive increase in strength acquired by the mass, and it attains the greater part of its ultimate value in about a year. Even after this period it is subject to a small progressive increase $(42)^{2}$.

In general the properties of setting cement are to be found both in mortars, or mixtures of cement and sand, and in concretes, or mixtures of cement, sand and broken stone, these chemically inert materials added to the cement exerting a physical influnce on metamorphism.

\section{Chemical Composition}

The chemical composition of normal Portland cement is shown in the following tables:

Average of 300 Normal Ameriran Portland Cements, Representing 20 lsiands of All Types

(Analyses ly the writer for the Board of Water suply)

\begin{tabular}{|c|c|c|c|}
\hline & Maximum & Minimum & A verage \\
\hline $\mathrm{SiO}_{2} \ldots \ldots \ldots$ & 2.5.8!) & 19.85 & 20.70 \\
\hline $\mathrm{Fe}_{2} \mathrm{O}_{3} \ldots \ldots \ldots \ldots \ldots \ldots \ldots \ldots$ & 4.0. & 1.2 .3 & 2.73 \\
\hline$\ldots \ldots \ldots \ldots \ldots \ldots$ & 9.16 & 3.43 & 6.17 \\
\hline$\ldots \ldots \ldots \ldots \ldots \ldots$ & $(;+.91$ & 59.06 & $(i 2) .(i \overline{1}$ \\
\hline 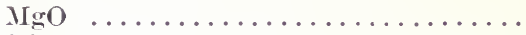 & 4.00 & 0.30 & 2.19 \\
\hline 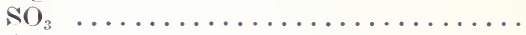 & 1.75 & 0.84 & 1.37 \\
\hline 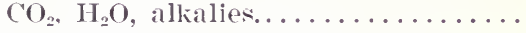 & $\cdots$ & $\ldots \ldots$ & 2.17 \\
\hline
\end{tabular}

levage of 100 German Portland Cements

(Burchartz, (12))

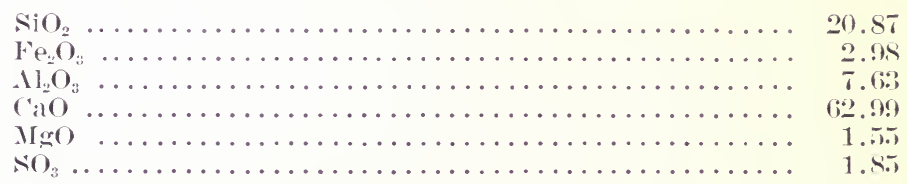

The ultimate chemical composition of a cement is only, howerer. a rather indirect clue to its hydraulic properties, just as the ultimate analysis of a composite rock may only give a faint idea as to its constituent minerals or possible products of metamorphism. For example, it would be quite possible to synthesize a mixture which would, on analysis, correspond exactly to the chemical composition of an excellent Portland cement, yet which, when gaged with water in the ordinary way, would derelop practically no tensile strength, in fact would possibly fail to set at all.

Cement, therefore, must owe its hydraulic possibilities to a particular grouping of its constituent compounds, quite analogous to a series of

\footnotetext{
${ }^{2}$ Numbers in parentheses refer to the bibliography at the end of this article.
} 
minerals; and looking to the identification and classification of these minerals, a great deal of investigation has been done.

By trial burnings of simplified mixtures, such as lime-silica melts, and by microscopical examination of sections of the resulting clinker, the problem is gradually being clarified, but, owing to its great complexity, much controversial literature thereon has been issued on both sides of the Atlantic $(52,69,80,64,65,88)$. The theories put forth have so far had little practical effect upon the manufacture and composition of the commercial product (63).

No complete and final enumeration of the chemical compounds resulting from the burning of such a mixture of clay and limestone has ret been accepted as authoritative. The microscopical identification of the individual chemical compounds which go to make up the mineralogical entities is at best somewhat unsatisfactory, especially because of the minuteness of the particles of raw materials necessary to secure thorough and uniform calcination, and consequently the extremely small size of the resulting erystals and aggregates. It has been proposed, in this connection, to secure these of a size available for study by the expedient of fusing the clinker in an electric furnace; and, by this means, a partial clarification of the system has been obtained (103).

\section{Mineralogical Constitution}

The minerals which are recognized in cement clinker have been named alit, belit, felit and celit (101), and a metamorphism ${ }^{3}$ of these occasioned by the action of water is the cause of the setting and hardening of Portland cement.

Alit has been reported a solid solution of tri-calcic silicate in tri-calcic aluminate, and celit a solution of di-calcic aluminate in di-calcic silicate (61). Other investigators have reported alit and celit to be silicates of different silicic acids (26).

Belit is probably a calcium aluminum silicate of the composition $\mathrm{Ca}_{3} \mathrm{Al}_{2} \mathrm{Si}_{2} \mathrm{O}_{10}$, a form found in nature as the mineral gehlenite (27).

\section{Setting Process}

Precisely what chemical reactions and physical transformations take place in the setting and hardening processes is not yet definitely settled. It may, however, be stated that by modifying the proportions of clay to limestone through a certain range, we obtain a product which varies in its speed of setting and of hardening. In general, cements high in silica

\footnotetext{
${ }^{3}$ Metamorphism : Any change in the constitution of any kind of rock, Van Hise (104).
} 
are found slow setting and slow hardening, while those high in alumina are quick setting and quick hardening. An increase of lime in the latter retards the setting (63).

The calcium aluminates are probably the main factors in the setting of cement, while the hardening is due to the calcium silicates. The magnesium compounds are inessential to the hydranlic processes (105).

Upon the addition of water to cement, the equilibrium in the system of solid solutions and chemical compounds is destroyed, and a series of changes is inaugurated tending towards the production of a system which will be stable under the new conditions. The first effect resulting from the solutions and reactions brought about by the presence of water is the setting of the plastic mass.

Under ordinary conditions of practise, the quantity of water nsed is about 22 per cent in the case of a neat cement, being less in the case of a mortar, and still less in the ease of a concrete. When this proportion of water is used, it is probable that the setting of rement is mechanically analogous to the setting of plaster of Paris and is caused by the growth throwghout the mass of a network of crystals, deposited from the saturated solution formed by the first stage of hydro-metamorphism.

Owing to the low solubility in water of the original component substances, the attainment of final equilibrium is a matter of considerable time, and is further delayed by the automatic protective action of films of insoluble substances coating the active particles (23). These film. in some cases are semi-permeable, and exert a selective influence upon the solutions osmotically penetrating them. Under normal conditions, that is under those conditions which have been found in practise to yield the densest and strongest product, this attainment of equilibrium considered apart from the setting process at first proceeds rapidly, but the rate of increase of strength grows smaller, tending to a minimum.

A. Erskine Smith has shown (90) that there has been no permanent retrogression in the strength of cement in the case of specimens kept under observation for 21 years. Of course, this relates to laboratory specimens protected from weathering, but shows one of the directions which this metamorphism may take.

\section{Hardexing Process}

The hardening of cement has been ascribed rariously (48)

1. To the fineness of grinding,

2. To the increasing stability of calcium compounds due to combination of part of the silicic acid as the silicates grow less basic,

3. To the action of free lime upon calcium compounds, 
4. To the decomposition of basic products present in the freshly set cement,

5. T'o equilibrium of calcium hydroxide with the siliceous constituents, and

6. To the hydration of the double silicates and anhydrides of lime and alumina.

The two theories that have at present the greatest claim upon consideration are that the strength of set cement is due to the progressive crystallization of calcium hydroxide $(80)$, and, in some respects diametrically opposed, that this strength is due to the formation of a dense complex colloid, soft at first but gradually adsorbing calcium hydroxide and thus becoming harder and harder $(64,65)$.

According to the latter theory, cement consists of a mixture of fused compounds of silicic, aluminic and ferric acids with lime, together with an excess of lime, partly dissolved and partly enclosed. Upon the addition of water to this system it is decomposed, and the water becomes a supersaturated solution of salts, which react between themselves. The compounds resulting from these reactions crystallize about the cement grains in needle-shaped crystals. So far, the process is analogous to the setting of plaster of Paris (45), and silica takes no part in these preliminary reactions.

A hydrogel begins to form about each grain, in which the crystals become embedded. This hydrogel consists essentially of calcium hydrosilicate, and to a minor degree of calcium hydroaluminate and calcium hydroferrite. At first it is soft and plastic, but gradually becomes dense and rigid by the adsorption of calcium hydroxide. The strength of cement is mainly due to this process of coagulation.

The calcium hydroxide may of course crystallize and lend additional strength; but its erystallization is rather more likely to burst the hardened cell walls about each grain of cement, and thus admit liquids later in the process which may be fatal to the integrity of the structure, either by undesirable chemical reactions, or simply by dissolving away the lime, with the formation of soft hydrates of silica, alumina and iron oxide, instead of the desired hardened colloid $(64,65)$.

Much corroborative evidence has been offered by supporters of this view, and similarly by the exponents of the crystallization theory in defense of that. The question is still at issue, and the main difficulty is the microscopic recognition of the constituents of set cement $(34,78)$, Unquestionably, colloidal materials result from the action of water on silicates of this type, when the particles have been ground to the fineness of Portland cement $(23,21,95)$. This has been directly observed in the 
case of cement and reproduced with synthetic mixtures. What binding power colloidal material may develop is strikingly seen in the case of conglomerates and sandstones in which hydrous silicic acid, aluminic hydroxide or ferric hydroxide has been the cementing material, so that the theory is attended by a high degree of probability.

On the other hand, it is also quite conceivable that the interlocking of crystalline masses between the grains of cement may account in some measure for the strength. There is definite evidence that calcium hydroxide does crystallize, and its mineralogical and crystallographic constants have been determined (2t).

The two views are not entirely irreconcilable, and it is possible and even probable that, mechanically, the strength of cement acquired by hardening is due to both processes. Whatever be the chemical reactions in detail by which these elements of the structure are produced, the main condition for their occurrence is the presence of water.

This paper is deroted to an enumeration of the factors which influence the metamorphism caused by water in Portland cement, and the variations in the physical properties of the resulting rock, brought about by varying these factors.

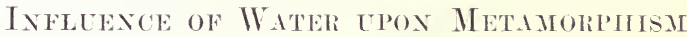

The action of water upon Portland cement is a resultant of

1. The temperature of the water

A. At first added

B. That may subsequently come into contact with the system

2. The quantity of water

A. At first added ${ }^{4}$

a. Size of cement particles

b. Mechanical agitation when water is adder

c. Total water added

B. That may subsequently come into contact with the system

3. The quality of water

A. At first added

a. Having material in solution

B. That may subsequently come into contact with the system

a. Having material in solution

b. Haring material in suspension

\footnotetext{
* Owing to the peculiar autoprotective reaction of cement against the action of water, before alluded to, the quantity of water coming into contact with cement is a function of the size of the particles and of mechanical stripping of protective films, as well as of the ratio of cement to water.
} 
The final effects of geological processes do not differ in the main, whether these operate upon natural substances or upon the products of human industry. The agent whose activity is responsible for the majority of terrestrial changes, namely water, is also the main factor in the metamorphism, of the artificial rock, cement. By intelligent control of the action of water upon this rock, the desired results are obtained, and its value as a material of construction is inestimable. Lacking this insight, the action of water may result in catastrophe, or at least loss of time, money or efficiency. Geology, then, through hydrology (59), is enabled to give substantial aid to the engineer.

\section{TEMPERATURE OF TIIE WATER A'T FIRST ADDED}

In construction, the water at first added to cement, known as the gaging or mixing water, is subject to the entire range of variation of atmospheric temperature. The lower limit is far below the freezing temperature of water and of course, in this phase, water is useless for the purpose.

Within the possible range of temperature under working conditions, it has been established that as the temperature of the gaging water used is higher, the set becomes more rapid. Considering the setting due to the deposition of a network of crystals from the supersaturated mixing water, the beginning of this deposition would be sooner attained, if the water reached its condition of supersaturation more quickly; and this condition would be brought about by a higher original temperature, provided, of course, that the solutes increased in solubility with the temperature. With a higher temperature, the volume of the water would be greater and the riscosity less, and consequently its range of activity would be increased; that is, it would be enabled to reach a larger number of cement particles and thereby more quickly arrive at its saturation point, and the deposition of the crystalline network hastened in consequence. If the temperature of the mixing water be above about $37^{\circ} \mathrm{C}$., the setting, instead of being hastened, begins to be delayed. If the deposition of this network were a simple case of precipitation from a hot solution, it would be logical to state that the solubility of the compounds concerned was so high at this temperature that they were not deposited from solution. The problem, however, seems chemical rather than physical, and it is more probable that this effect is due to hydrolysis.

Hydrolysis increases with the temperature. In the case of the weak salts that must exist in the system we have under consideration, the ultimate products of hydrolysis are the gelatinous materials-silica, in the hydrated form, aluminic hydroxide and ferric hydroxide. The adsorp- 
tive and coagulative properties of these materials unquestionably do not compare with the coagulative powers of the complex colloid which Michaelis postulates $(64,65)$. If, therefore, the hydration of cement does not proceed in a properly regulated manner, it is conceivable that it may become a hydrolysis, with deleterious effects.

If the mixed cement is allowed to freeze, the setting will not take place, but on thawing out the mass, setting is resumed. Obriously the transition of the water to the solid phase hinders solution and diffusion, and upon resuming the liquid form, water promotes these processes as before. A slow setting has, howerer, been observed in frozen mixes (94), and it is quite possible that the phenomenon of regelation mar account for this.

Smoke gases have been found to have a disintegrating effect upon rement setting at a temperature lower than $7^{\circ} \mathrm{C}$; this is attributed to the formation at these temperatures of a hydrated calcium carbonate, haring the formula $\mathrm{CaCO}_{3}, 5 \mathrm{H}_{2} \mathrm{O}$ by the action of the carbon dioxide of the smoke gases upon the lime of the cement. At slightly higher temperatures this hydrate is transformed to pulverulent calcium carbonate, with consequent disintegration of the structure of which it forms a part (10 ).

The effects of moderate rariations in the temperature of the mixing water upon ultimate strength are practically of no great moment: even mixes that have been frozen and afterwards allowed to resume their sot are not materially affected in their ultimate strength, if the set has not proceeded too far at the time of freezing (11). More than one repetition of the freezing process upon the same mix, howerer. will be quite destructive to the final hardening.

If the hardening be considered a process of crystallization. repeated freezing may be assumed to destroy the strength by the formation. through rapid temperature (hanges of relatively small and non-arthesive crystals of the calcium hydroxide during the critical foundation period of growth of the crystalline structure, so impeding and misclirecting consequent interlocking that a weak structure results.

If, on the other hand, the colloidal theory is adhered to, it is only necessary to point ont that the colloidal cell walls about the cement grains may be ruptured by the expansion of the contained water in freezing. This would result in discontinuity of the internal structure, and if sufficiently widespread, as would be the ase in repeated freezings, would alone account for weakness.

Studies have been made of the ultimate resistance obtained from frozen mortars by rarying the amount of gaging water, with the riew of estab- 
lishing whether "wet" or "dry" mixes best resist the disruptive effects of frost during setting. The results reported are discordant. An excess of water has been found by one investigator to enhance the effects of frost (85), while by another it has been found to diminish them (11). Theoretically, the disruptive effects of freezing should be enhanced by the presence in the mass of larger quantities of gaging water. On the other hand, it can be assumed from the colloidal standpoint that an increase in the amount of water present will result in the formation of a greater quantity of colloids and a greater elasticity of the resulting mass, together with a smaller total breakage of cell-wall material.

TEMPERATURE OF THE WATER THAT MAY SUBSEQUENTLY COME INTO CONTACT WITH TH!E SISTEM

The action of hot and boiling water upon set cement is strongly marked in the case of cement which contains free lime, producing after a few hours, swelling, distortion and cracking and even total disintegration. A normal cement so treated, however, preserves its original form and volume after short periods of exposure to the boiling temperature.

The viscosity of water at high temperatures is greatly diminished, and the liquid is thereby enabled to penetrate more rapidly the capillary and subcapillary voids, thus reaching more quickly a larger internal area. If, as in the case of an unsound cement, free lime is thereby reached, this is slaked much sooner than it would be nnder normal conditions, and moreover with great violence, owing to the higher temperature of the water, producing internal disruption, and perhaps thus opening up further arenues to the penetration of water, with a repetition of the slaking process.

The boiling test here described is a very important one in the testing of cement for construction, but it is perhaps less reliable in the case of unsoundness from the presence of excess of magnesia.

In cements stored in waters of relatively high temperature, it is probable that the processes of solution act more rapidly, from the two reasons mentioned abore; but evidence is lacking to show that any significant decrease in ultimate strength is thereby occasioned.

Data as to the storing of cement in waters of low temperature, yet not subjected to the action of frost, are not arailable in the literature, but they would be interesting.

In the case of exposure to the action of frost, the process is quite similar to that which goes on in the disintegration of natural rocks and depends, in like manner, upon the initial mechanical resistance of the 
mass, upon the total volume of the roids and upon the ratio of eapillary to subeapillary roids. The disruptive effect is, of course, due to the expansion of the water during freezing. Consequently there is a possibility that during the earlier stages of the history of the mass this effect may be to a great extent neutralized by the presence of soft colloidal material $(45)$, because of its lack of rigidity.

Toids are undoubtedly present even in neat eement mixes, and they are more common in mortars and in eoneretes; when, therefore, these have attained a sufficient hardness, they are in all respects similar to a natural rock and subject to the same katamorphie processes. 'The effect of frost inereases in intensity as the mass ages and loses elasticity.

As water permeates the eement, even after hardening has progressed to a considerable extent, it becomes charged with various electrolytes, and its freezing point is consequently lowered. To some extent this immunizes the mass from frost action. On the other hand, as we have seen before, cryohydric compounds may be formed at these low temperatures, and the separation of these from solution is a factor in the opposite arirection.

QUANTITY OF WATER AT FIRST IDDED

size of cement particles.-'The finest particles in cement, provided that they are chemically identical with the remainder, are the most active cementitionsly, because of the ease of reaction and of the greater probability of this action being uniform throughout the mass of each particle. This is recognized under the microscope by the ultimate disappearance of these particles as individuals upon the addition of water. Owing to the relative insolubility of the constitnents of cement, both before and after metamorphism, each particle becomes covered to a certain depth with the reaction products, which in this case take the shape of gelatinous films (2) in such manner as to offer hindrance to the further action of water.

The particles whose diameter is smaller than or equal to the thickness of this zone evidently are the most efficient ehemically. The larger partieles are less so. as the passage of water through the enreloping film is a slow matter, and some particles may be so large as to remain internally unchanged. It is probably this fact that gives a hydraulie quality to previously set cement that has been reground and retempered with water; in fact, this process may be repeated a number of times with the same sample of cement.

Tot all of each particle, therefore, can take part in the setting and hardening, and sometimes this proportion of inert material is eonsider- 
able $(86)$. The coarser particles are comparatively inert and might be replaced by grains of foreign material of the same size without materially influencing the ultimate strength of the resulting mass. This has been demonstrated experimentally (1\%). It does not follow, however, that a cement consisting entirely of uniformly very fine particles would be a desideratum, since such a cement would not pack as well as one containing a greater variety of sizes, and the increase in chemical activity would be markedly overbalanced by the imperfection of structure of the mass. Considering each particle to be spherical, and of equal size with every other, when packed in the most compact manner possible the pore space would be nearly 26 per cent (89). The points of contact of the adjacent spheres, notwithstanding the tendency of the gelatinous envelope to spread, would be relatively few. If, however, this pore space were filled with finer material, the structure would develop more strength. The function of part of the cement is to remain passive and to add to the strength of the structure merely by its action of roid-filling. Extremely fine grinding has been found to decrease the ultimate strength, if the cement is used neat, but to give greater strength, if the cement is used in a sand mortar $(62)$.

As might be expected from the above considerations, the fineness of grinding has an accelerating effect upon setting. Cement ground in a tube mill until only 1 per cent remained on a sieve having 5000 meshes per sq. cm., was so quick setting that it could not be restrained eren by the addition of 10 per cent of gypsum (4\%). When cement is relatively coarsely ground, the ultimate strength is not so quickly attained, but its acquisition is regular and uniform.

Laitance.-In concrete construction under water, especially salt water, there gathers about the freshly deposited concrete a milky white cloud of suspended matter, technically known as laitance. This material is also formed when concrete is mixed rery wet, though not deposited under water.

In analysis of laitance by the writer, marle for the Board of Water supply, practically coincides with an analysis made by Richardson (9々) and leads to the same conclusion as that reached by him; namely, that laitance represents an actual loss of cement and consists of the finest particles of cement which have been washed out of the concrete. The additional conclusion is justified that this portion of the cement, by reason of the small size of its units, has been so acted upon by an excess of water that it has undergone complete hydrolytic decomposition, before the colloidal enveloping film had adsorbed sufficient electrolytes to completely coagulate it and so render it largely impermeable. This is substantiater by the fact that laitance possesses neither setting nor hartening qualities. 
Hydrolysis theory.-The formation of such a protective film upon the surface of a coarse particle will so regulate the access of water to its interior that the contents will be slowly and normally hydrated. If the entire mass of the particle were at once accessible to an excess of water, the weakly acid and basic compounds at first formed would soon be hydrolysed and shorn of their binding power, and instead of the normal complex colloids described by Michaelis $(64,65)$, capable of adsorbing electrolytes and so coagulating into a dense rigid mass, simpler colloids such as hydrous silicic acid and aluminic hydroxide would form, which have not these powers to so high a degree.

Finally, the rate of setting and hardening of a cement may be considered a function of the proportion of fine particles present. Mortars set and harden more slowly than neat cement, and concretes more slowly than either. This is simply a development of the fact that coarsely ground cement sets and hardens more slowly than that which is finely ground. It may be considered, from another viewpoint, that the inactive material interferes with the liberation of heat from the system, and that chemical reaction is consequently delayed in proportion to the amount of inert material present.

Mechanical agitation when uater is added.-If cement in the state of a plastic mass be worked and kneaded, the ultimate strength will benefit thereby, up to a maximum time of working. It is legitimate, a priori, to surmise that the setting is hastened, within limits, although no record of this is found.

After the maximum time referred to, which in experiments made at the Board of Water Supply laboratory has been found to correspond roughly with the time of initial set, continued working will cause a falling off in the strength. Up to this time, mechanical agitation with the proper amount of gaging water will cause an increase in the ultimate strength.

The formation of the erystalline network, which constitutes the setting of cement, and which is responsible for the primary strength by holding the plastic mass rigid and in place, while the more important element. of hardening make their appearance, is unquestionably facilitated by agitation. Stirring is a means of hastening chemical reactions by bringing the agents into more intimate contact. The compounds that go to make up this network, being sooner brought into solution, perform their function more quickly, and the crystals begin to form. Instead, however, of forming a continuous rigid network, the crystals will be smaller and less cohesive than if undisturbed in their growth. and the set can be delayed and even prevented by continuing the agitation long enough. 
The ultimate resistance of cement which has been thus treated is decreased as well. The formation of the coagulated colloid, or of the interlocking crystal units, whichever may be the cause of hardening, is rendered imperfect and discontinuons, and the structure reflects the weakness of its component units.

It may moreover be supposed that more cement has been brought within the range of hydrolysis by this agitation, and so converted into laitance, even the larger particles being stripped of their protecting films by the attrition. 'Tests made at the Watertown Arsenal (36) showed that after one hour's working, cement had gained $t$ per cent over the normal strength, but that after 10 hours' working, it harl lost $2 \pm$ per cent from the normal, in 20 hours 38 per éent, in 50 hours 56 per cent and in 100 hours 69) per cent.

Total quantity of nater at first added.-Under certain conditions, the entire range of particles of a cement might be destructively hydrolysed, resulting in what is termed "Arowned" cement. 'The effect of an increase in the quantity of mixing water is known to result in a diminution of strength, and, bearing in mind what has been previously said regarding hycholysis, the reason is clear. If, before the cementing of contiguous particles, an excessive amount of water is admitted to contact with the cement, colloidal material will form in increased amount. It has been shown that an increased amount of mixing water results in an increased rolume of the paste produced (39). This indicates that a larger amount of the products of hydrolysis is formed.

Owing to difference in composition between these hydrogels and those formed under normal conditions, they are incapable, as has been before observed, of adsorbing electrolytes in such degree as to attain to the density and rigidity of the latter. Admitting, on the other hand, that colloids so formed do not differ in composition from those formed in the normal hardening of cement, there still remains the abnormality of the structure formed in this way. Being discontimuous, it would not offer the same total resistance, in the form of connected films, to the passage of water. Moreover, in the presence of an excess of water the working ratio of electrolytes to colloids would be less because of the greater dilution in proportion to the rolume of eolloid.

QLANTITY OF WATER TIAT MAY SLBSEQLENTLY COME INTO COXTACT WITH THE SYSTEM

The effect of water upon cement after it has completely set rapidly diminishes to a negligible quantity at ordinary temperatures, if the water is reasonably free from dissolved or suspended impurities. There is a 
leaching out of calcium hydroxide from the mass of the cement; but this diminishes as the mass grows more and more impermeable, by the coagulation of the colloidal cell walls and by the carbonation or other precipitation of lime salts in the pores.

This deposition of lime salts in the pores is eridently the canse of higher strength in specimens which are allowed to dry out a few hours before testing. It is analogous to the higher strength dereloped by seasoned stone than by freshly quarried stone, occasioned by the eraporation of the "quarry sap." In addition, the carbon dioxide conveyed to the material in a gaseons form is absorbed by the lime and may be considered a positive factor towards strength, while that conveyed in solution (where the cement is under water) is a negative factor, in that it accelerates the solvent effect of the water coming into contact with the cement. On the other hand, cement specimens which are entirely air-hardened are mquestionably weaker, by reason of the absence through evaporation of the requisite amount of water for proper hydration.

Then the action of water upon set cement is intermittent, the solvent effect manifests itself by unsightly incrustations and discolorations (3), cansed by dissolved material brought to the surface through capillary action and there deposited by eraporation. When the mass is permanently under water, these salts are merely washed away. The danger from these incrustations, although slight, is the disintegrating effect produced by their increase in rolume, through erystallization or efflorescence, and the consequent disruption of the denser surface skin, rendering easier the action of frost upon the entire mass.

This surface skin is improved by troweling the cement while in a plastic state, and consists of a closely packed layer of fine particles, which offers high resistance to permeation by water and comparative immunity from the solvent action farored by a rough, porous or fractured surface.

If the mass be placed in water before setting, it is more liable to hydrolysis, as evidenced by the copions formation of laitance; and if greatly exposed, as by agitation under water, it may fail to develop the greater portion of its normal ultimate strength. To prevent this, care is taken, in laying concrete under water, so to convey it that it offers the least possible surface to water action during its descent; and to this end it is either lowered in cloth bags, or filled in through a chute, so as to escape all aroidable exposure to hydrolysis.

If the water which comes in contact with a cement structure be under considerable pressure, so that its tendency is to percolate through the mass, the solvent effects will of course be magnified, proportionally to the porosity of the mix; and experiments made by the Board of Water Supply 
hare shown that concrete subjected to such percolation has been shorn of the major portion of its ultimate strength. In this case, the solvent effect of the water is only part of the influence at work, purely mechanical factors entering largely into the destructive process, as will be shown later.

Stalactitic growths of lime salts form as the result of water percolating through concrete. Micro-organisms of the algal type frequently lodge in the pores of concrete and by their growth may act as a protective influence against the permeation of water. The effect of their products of metabolism and decay upon the concrete structure has not been studied.

Numerous waterproofing materials and processes have been devised $(40,73)$. They may be grouped conveniently under three heads.

Surface treatments. - The application to the surface of concrete of a coating similar to a paint has the disadrantage that concrete is not a thoroughly dry material. Where the rehicle is a liquid immiscible with water, the paint will not therefore come into contact with the concrete proper. If the rehicle is miscible with water, unless insoluble products are at once formed by reaction with the constituents of cement, the active agent is quickly leached out.

Membranes.-These are layers of waterproof tissue interposed betweer two layers of the concrete. 'There is strong probability that these never actually form a bond with the concrete, and thus they necessarily introduce an element of weakness and heterogeneity.

Mass treatments.-The active material is incorporated with the concrete at the time of mixing, either by dissolving or suspending in the gaging water, or by intimately mixing with the cement or sand. These treatments are many and differ widely in the agents employed. Substances of a waxy or fatty nature, triturated to a great fineness, are the most generally offered, but the incorporation of these in a mass of concrete is generally followed by weakness of the structure. The general problem of cement waterproofing has been conceded to be simply a question of roid-filling, yet this must be accomplished without the addition of inert material that will weaken the resulting structure.

The addition of more colloidal material has been suggested. This is ingeniously effected in a recent process by the use of hydrolysed cement, obtained by treating cement with an excess of water $(99)$. The paste so obtained is added to the cement during mixing.

The still unclarified state of our knowledge of the dhemistry of the setting and hardening of cement is the great handicap which has thus far prevented the devising of a satisfactory waterproofing agent. A large number of the waterproofing preparations on the market are therefore 
purely empirical, and not applicable to the practical waterproofing of large masses of constantly wet concrete. In the interests of efficiency, it is probably more economical to expend money destined for waterproofing in the purchase of additional cement to be used in making a richer concrete.

\section{QLALITY OF WATER AT FIRST ADDED}

IIacing material in solution.-On adding water to cement, heat is evolved, the temperature of the mix rising in some cases to above the boiling point of water. It is the custom to look with suspicion upon aements in which an excessive rise of temperature is obtained, as being liable to derelop unsoundness. The abnormal rise is attributed in some instances to the presence of free lime, in others to an insufficient proportion of lime. The volume changes caused by a rise in temperature have been given as the reason of the difficulty encountered in joining fresh rement surfaces to old, causing weakness at the plane of juncture, the sontraction of the mass on cooling breaking the joint before it has dereloped sufficient strength to resist the strain.

To prevent this, it has been suggested to coat the surface to which fresh cement is to be applied with a retempered mortar: that is. with a cement which has been treated with water after partial setting. This provides an intermediate course of material in which the temperature changes are not so rapid, and upon this course the fresh cement mixture is applied (35).

Upon the same principle may be explained the use. for a fresh course of cement which is to be joined to some which has previously set, of mixing water in which a quantity of cement has been stirred, thus retarding the chemical reaction and consequent temperature changes. In both ases, the active water is already charged with the soluble portion of cement, its solvent power for the same material is thereby diminished and the chemical action moderated, so that heat is more gradually evolved and violent expansions and contractions avoided.

'The influence of dissolved electrolytes in mixing water has received nuch careful study. Through the addition of a small percentage of some soluble salt to the mixing water, many have tried to influence the properties of the completed structure and to produce a mass that would develop greater strength or a higher degree of imperviousness. Unfortunately, the panacea has not as yet been discorered that is suitable for practical application.

The addition, similarly, of a soluble powder incorporated in the mass of the cement comes under the same category. In this connection, our 
attention is drawn to the effect of the usual addition of ground gypsum or of plaster of Paris to the ground clinker, for the purpose of retarding the set. There are other salts whose retarding influence on the set of ground elinker is comparable and probably superior to that of gypsum, but their use is not so practical, consequently, it has been adopted as the restrainer for general use.

It has been shown by Rohland (83) that the salts which respeetively accelerate and retard the setting of cement are the same as those which accelerate and retard the hydration of quicklime. From this it is concluded that their influence is "catalytic."

A detailed explanation of the mechanism of the action of gypsum has been put forth (79), holding that the presence of calcium ions in the mixing water, resulting from the solution of gypsum therein, decreases the solution of other calcium ions, thus retarding the solution of lime and the hydrolysis of the aluminates, which in turn retards the set.

It seems probable, upon this basis, that the presence of certain electrolytes in the mixing water acts upon the set by influencing the solubility of calcium sulphate therein, and consequently increasing or diminishing the number of calcium ions present in the mixing water as a result of the solution of calcium sulphate.

For example, sea water has been found to retard the set of cement (83). Gypsum, although a relatively insoluble salt, may be regarded as fairly soluble in moderately strong solutions of sodium chloride or of other salts having no common ion (14). In the presence of sodium chloride, then, the calcium ion concentration in the mixing water is raised, and the solution of the calcium aluminates diminished, with the effect of retarding the set. Sulphates have been found, when dissolver in the mixing water, to have the property of retarding the set, with the exception of aluminum sulphate and calcium sulphate when in low concentration. In view of the latter fact, it is evident that the above explanation is perhaps only a partial one.

A large number of other electrolytes and miscellaneons compounds hare been investigated and the results are recorded (83).

The effect of soluble constituents in the sand used for making concrete is by no means negligible (t) and may offer an explanation for many instances of puzzling behavior of the mixture.

Sea water has been and is, in many instances, still used for mixing concrete, and to the best of our knowledge, no cases of failure can be attributed to this cause alone. Apart from the influence upon setting, the presence of dissolved electrolytes in the mixing water seems to increase the strength of cement in the early periods, as far as reported results have 
shown (4). This may perhaps be due to an increase of coagulation of the colloidal constituents, by reason of the presence of salts of greater ionization than are generally present. On the basis of the crystallization theory, this phenomenon is rather difficult to interpret.

\section{QUALITY OF WATER THAT MAY SUBSEQUENTLY COME INTO CONTACT WITH THE SISTEM}

Haring material in solution.-A large number of failures in concrete structures have been attributed to the disintegrating action thereon of water impregnated with varions salts. Inasmuch as all ground water is charged to some degree with salts which it has accumulated in its passage through the soil and rocks, this problem is worthy of the most careful attention. For our purpose, such mineral-laden waters may be dividert into

1. Sea water

2. Alkali water (from western alkali soils)

3. Deep rock waters.

The mineral constituents are common in all these cases, and vary only in the prominence of one or more of them. Thus in sea water the chlorides of sodium and magnesium, in alkali water the alkaline carbonates, and in deep rock water the chlorides of calcium and magnesium and the sulphate of magnesium are the distinctire constituents. Whether the effect of these electrolytes is cumulative, so that the continued action of solutions of low concentrations will work harm, or if not, what are the limiting concentrations to assure safety to the structure, has not been worked out. Obriously, it is not a laboratory problem, since the factors which obtain in nature are impossible to duplicate on a small scale. The solution lies in careful inquiry into the mechanism of the action and in observation of the instances of failure in construction work, with a sturly of its causes.

Sea water.-The effects of sea water upon set cement have been summarized in the statement by Feret, "No cement has yet been found which presents absolute security against the decomposing action of sea water" $(9 \tau)$. Le ('hatelier, after a series of experiments extending over ten years, confirms this conclusion (53). Poulsen concludes, howerer, that the chemical action of salt water is not alone sufficient to cause Portland cement mortars to deteriorate ( $r 6)$.

The diversity of results reported in the observation of the action of sea water upon cement indicates that there are varying factors at work that so far have not been clearly recognizen. Whether the precise nature 
of the action is physical or chemical is not quite settled. There are not lacking investigators who assert that the destructive action is mostly physical and is due, among other causes, to intermittent submergence and consequent deposition, by evaporation of crystals in the pores of the structure, which, either by their pressure of formation or by expansion during efflorescence, have a disruptive effect similar to that of frost (98).

There are those who hold that the action is entirely physical, and is due to this factor and the effects of frost $(91,102)$, although probably the latter is seldom the case in sea water, owing to its low freezing point (50). The effect of direct sunshine has been found deleterious when alternating with that of tidal action (20). Undoubtedly, all of these factors contribute to the total effect, and there is as well a marker chemical action.

The chemical effects of sea water upon cement are capable of various interpretations. They are summarized as the formation of complexes by the action of the dissolved sulphates and chlorides in the water upon the calcium silicates and aluminates of the cement $(\boldsymbol{7} \pm)$. It has been stated that sodium chloride solutions have the power of dissolving calcium silicate with the formation of an unknown salt $(58,70)$, and also that the sodium chloride enters into combination in the mass, the chlorine ion entering into the combination calcium chloro-aluminate, and the sodium. ion combining with lime, silica and alumina, to form compounds of the nature of the zeolites.

Working with strong solutions of the individual salts of sea water, it has been found that the chief harmful constituent is magnesium sulphate, and it has been suggested that this salt reacts with the lime of the cement to form calcium sulphate and magnesium hydroxide. The calcium sulphate further reacts with calcium aluminate to form a calcium sulphoaluminate, which by swelling causes the disruption of the mass. The magnesium hydroxide formed has been regarded as a restraining agent, by virtue of its filling up the pores of the cement and preventing further ingress of sea water (70). Again, the disruption has been directly attributed to the increase of rolume caused by the formation of this magnesium hydroxide (46). It has been calculated that, apart from the formation of hypothetical sulpho-aluminates, a molecularly equivalent amount of calcium sulphate replacing the calcium hydroxide of the cement occupies 2.08 times as much space and is, therefore, the cause of the disintegration (13).

Alkali and deep rock waters.-Burke and Pinckner (13) have formulated a working theory of the action of the rarious salts common to all natural waters. They attribute the disruptive action to more rapid re- 
moval of the calcium hydroxide, and in some cases to its replacement by material occupying greater volume, as before shown, and consequent disintegration of the structure.

That some such reactions occur is indubitable, and that the mechanical factors are a large influence in the disintegration is equally certain. An additional cause which may be of great importance has hitherto been neglected. The electrolytes in these natural waters may act as accelerators of hydrolysis, and, in effect, cement which is in contact with sea water is subject to the same action as that of an excess of water from any cause. By the presence of these electrolytes the hydrolysis of a larger proportion of the cement is effecterl and the results are increase in the volume of the hydrolysed portion, and production of a larger proportion of inert colloids. It has been found that a larger amount of cement can be converted into colloidal matter by the presence of an electrolyte in the water with which it is treated (99), and also that the speed of hydration of cement is affected by the presence and proportion of electrolytes present (84). 'The fact that a larger amount of laitance appears to be formed in sea-water construction also seems to bear out this theory.

Besides the reactions mentioned, set cement is subject to the replacement of silicic acid by carbonic acid, as are the natural rocks. Especially is this true in cases where the cement comes into contact with marsh and peaty waters and waters containing ferrous carbonate, which by transformation to the hydroxide liberates carbon dioxide $(24)$, which has been found to act, not only upon the calcium hydroxicle but also upon the silicates and aluminates (28).

The presence of free acids in water which acts upon the cement in quite destructive, in proportion to the concentration of the acid and to its strength or weakness as an acil. It is quite probable, howerer, that the liberation of colloidal silica by the action of acids would serve to a great extent as a protective influence against their further action.

Sewage gases are generally effective by reason of the hydrogen sulphide which they contain. This gas is readily oxidized to sulphuric acid, and then its action is the production of soluble calcium and aluminum sulphates, which are subsequently leached ont from the mass. This action has been found greatest at the surface of the liquid (106). Hydrogen sulphicle may also act by converting the iron of the cement into sulphicle, and this becomes oxidized into ferrous sulphate and is leached out, or by its expansion canses dispuption (28).

The action of many other inorganic and organic solutions has been observed, but they do not come within the scope of this paper, since they are not met with in natural proceseses. 
In general, the consideration is worthy of attention whether concrete structures which are under stress are not more liable to chemical disintegration than those which are in repose, or whether a single structure is not more liable to this action in its strained parts than in those not so affected. We have data to show that strained iron is more liable to corrosion than unstrained, and it has been asserted that strained minerals are more acted upon by underground solutions (104).

A number of protective measures against the action of saline waters upon concrete have been suggested and tried, but none has been so strikingly effective as to achieve universal recognition. The simplest remedy suggested is to make the concrete for such uses denser and more impervious by the employment of a greater proportion of cement, yet this may not always be practicable. When concrete is exposed to the gases resulting from the decomposition of sewage, it is suggested that even such a proceeding may be of no avail (29).

Previous air-hardening of the concrete before laying under sea water is acquiring more widespread use and is highly recommended (8\%). The cause of its protective action is attributer to the carbonation of the calcium hydroxide (48).

Tariations in the fineness of grinding and in the chemical composition of the cement used in concrete for sea-water construction have been proposed. The French specifications for sea-water cements call for a finer grinding than that which is required for ordinary construction. Much has been claimed regarding the resistance to disintegration offered by the so-called "iron ore" cement, which contains a minimum of alumina, this being almost entirely replaced by iron.

IIaving material in suspension.-The peculiar nature of the series of compounds forming and formed from cement, in that they are all of relatively low solubility, tends, as has been before observed, to retard the reactions which may occur. Mechanical agitation, by promoting diffusion and by transporting the reacting materials to their possible spheres of action, will accelerate these reactions. 'The motion of water, per se, (an and does produce this effect, and when the water is armed with suspencled material, its activity in this direction is greatly enhanced.

Where water has immediate access only to the outer surface of a mass of set cement and its pressure is low, the effect is a slow corrasion of the dense surface skin and ultimate removal thereof, rendering the interior gradually more accessible. Ordinarily, this process is a slow one, although under certain conditions, as in coast protection works where the velocity of the water is high and the suspended material coarse and plentiful, the destructive effects are more to be reckoned witl. 
The effects from less spectacular processes are quite surprising. Where the pressure of the water is such that there is a marked motion of the water within the pores of the concrete, the erosion is internal and far more insidious. In this case, the suspended material is part of the structure itself. Small particles of cement or, in the case of mortar, grains of sand which become detached from the parent mass are whirled around by the water stream and shortly enlarge the carity in which they are rotating, until it merges with some adjacent cavity. Under favorable conditions this process may continue until the interior of the structure is greatly weakened.

A factor which to some extent neutralizes the flow of water through concrete is the choking of the pores by sediment, coming from the water itself or furnished by the action of the water upon the concrete. If the flow is oscillatory, as in concrete exposed to the range of the tides, this protective effect will of course not be so marked ( 54$)$.

Diatoms and other microscopic marine organisms with siliceous or calcareous tests undoubtedly play an extensive part in the preliminary. stages of this internal mechanical action, by choking the capillary spaces. At the same time, undoubtedly, the organic debris thus introduced may by its decomposition give rise to substances, carbon dioxide and hydrogen sulphide, for example, which have an accelerating action upon the processes of solution, and the silting effect may thus be neutralized or even overbalanced.

\section{PART II}

\section{Experimental Ixvestigation}

In Part I, the ways in which water may influence the metamorphism of Portland cement were discussed qualitatively, and their possible effects upon the permanence of the structure of which cement forms the basis were pointed out. This question has now assumed economic and rital importance.

In the following pages experimental data are offered. in elaboration of the outline laid down in the first portion of the paper. Points in the scheme which have been established beyond doubt by previous investigators are here omitted, and only such results are inserted as have been deemed necessary as additional evidence. The last division of the outline, treating of the action of suspended material in water in effecting the erosion of concrete, has not been experimented upon. not having come within the scope of the writer's activities, and therefore is omitted. 
Other divisions have already been so thoroughly covered by previous investigators that very little remains to be said about them. Emphasis has therefore been laid in this paper upon the little known fields.

The problems which confront the user of concrete are of a high order of complexity. The generalizations of chemistry are not yet sufficiently developed to apply rigidly to systems of so many variables, and experimental work on a laboratory scale often fails almost entirely to reproduce the conditions of practice. 'The best guide to the truth, then, is the pragmatic sanction of experience-the investigator in this field can but point out probable directions for future experimentation. The theories which underlie past success are a safe guide, nerertheless, to future construction, and the systematization thereof is a legitimate field of usefulness.

While, strictly speaking, any aggregation of chemical compounds might be considered a rock, whether natural or artificial, a majority of the cases conceivable under such a classification would not present important petrological problems in the study of their metamorphism. Such a problem as the action of water upon a mixture of sodium chloride and (alcium sulphate can be partly solved in vitro, even though the action of sea water upon gypsum deposits is an interesting petrological investigation.

'The important components of Portland cement are everywhere about us in nature, and the reactions by which it is made artificially have been taking place for many geological ages without the intervention of man. Silica, alumina and lime are among the most important constituents of the earth's crust; they are subjected in places to the same conditions that exist in the kiln, and are afterwards acted upon by water, under some of the same conditions under which man builds massive structures.

'The complex question of the history of rock magmas is not one to be solved by any one group of scientists, but by patient and concerted efforts of the chemist, the physicist and, above all, the petrologist. So the problem of the constitution of Portland cement may be as yet somewhat indeterminate; but an examination of the more general effects of metamorphism may reveal some identity with conditions in natural rocks already studied and may direct us to the correct methods for investigation of the constitution of cement $(6 \%)$.

Other important problems in the field of cement and concrete are referred to in the following pages, and belong in great measure to the field of petrology. Not the least important of these is the suitability of varions types of rocks for use as aggregates in concrete, and this work is claiming more widespread attention daily $(19,44,111)$. 


\section{TEMPERATURE OF THE WATER AT FIRST ADDED}

Two standard cements were gaged with the requisite quantity of mixing water for each at different temperatures. 'The effect upon the time of initial and final set was noted, as follows:

TABLE 1

Effect of 'Temperature of Gaging Water on Time of Initial and Final set

\begin{tabular}{|c|c|c|c|c|c|c|}
\hline \multicolumn{2}{|c|}{$\begin{array}{l}\text { Per cent by weight } \\
\text { of mixing water }\end{array}$} & \multirow{2}{*}{$\begin{array}{c}\text { Temperature of } \\
\text { mixing water } \\
A \text { and } B\end{array}$} & \multicolumn{2}{|c|}{$\begin{array}{l}\text { Initial set, } \\
\text { loours }\end{array}$} & \multicolumn{2}{|c|}{$\begin{array}{l}\text { Funal set. } \\
\text { hours }\end{array}$} \\
\hline A & B & & A & B & $A$ & B \\
\hline $2 \cdot 2$ & 21 & $70^{\circ} \mathrm{F}$. & 4.25 & 4.50 & 6.75 & 7.50 \\
\hline $2: 2$ & 21 & $100^{\circ} \mathrm{F}$. & 1.50 & 4.00 & 4.00 & 7.00 \\
\hline $2: 2$ & 21 & $150^{\circ} \mathrm{F}$. & 0.33 & 3.75 & 0.50 & 5.75 \\
\hline 22 & 21 & $212^{\circ} \mathrm{F}$ & 1.00 & 2.75 & 2.75 & 6.00 \\
\hline
\end{tabular}

The results seem to indicate that interference of hydrolytic decomposition with the setting appears between $150^{\circ} \mathrm{F}$. and the boiling point of water. Below these limits, the effect of increase of temperature of the mixing water, as is well known, is to increase the speed of setting (31). The setting time at these temperatures is a resultant of two opposed processes, - the formation of the water crystalline network, and the destructive hydrolytic action of water upon the original constituents of the cement, resulting in a product which has no hydraulic qualities.

Where the second process orerbalances the first is the point at which the speed of setting ceases to increase and begins to diminish.

This is true of course of the stage known technically as the final set (9). In the first few hours of setting. there is a period of relaxation, which McKenna has aptly termed reverse set, and which he has been able to detect with precision by means of an ingenious chronographic apparatus of his invention ( 60 ). The phenomenon has been observer by the writer and his associates in the laboratory of the Board of Water supply, using the Ticat needle; but this apparatus does not lend itself to a scientific study of the finer differences in rigidity which occur during the setting period. McKemna's apparatus should throw a great deal of light upon the initial metamorphism of cement.

TEMPERATLRE OF THE WATER THAT MAY SEBSEQLEXTLY (OME INTU CONTAC'T WITI TIIE SYSTEM

Migh messure steam.- Wig (109) has recently presented an account of the excellent effects of high pressure steam when used in curing con- 
crete. He found that by using conerete that had attained its initial set and exposing it to steam at 80 pounds pressure the six months' strength could be obtained in two days, a tremendous accelerating of the hardening process.

This state of affairs is not very satisfactorily explained, if the hardening of cement is supposed to be due to the progressive crystallization of caleium hydroxide, since it is somewhat at variance with our knowledge of the conditions of crystallization to assert that continuous exposure to a high temperature, presumably eonstant, should accelerate crystallization; particularly since in this case the amount of water present in the system remains the same. On the basis of the colloid theory, however, it is simply explained by supposing that adsorption of calcium hydroxide by the complex hydrogel is accelerated by higher temperatures.

Cold storage.-A series of tests, embracing neat cements and mortars, was marle upon tensile test specimens exposed, atter the age of $2+$ hours, to low temperatures under diverse conditions. The following conditions were observed:

1. ('hilling the briquettes at 24 hour's age by filling the storage tank with water at the lowest winter temperature as it came from the tap. The water was then allowed to come slowly to normal winter temperature for the tank, about $60^{\circ} \mathrm{F}$.

2. Chilling another set of specimens, otherwise normally treated, by filling the tank with cold water as before, $2+$ hours before breaking.

3. Storing another set in ice water for the entire period after remoring from the damp closet at $2+$ hours' age.

t. Normal treatment.

Two brands of well-known cement of high quality were run in parallel. The mortars were of proportions $1: 3$, Ottawa sand being used. The results obtained are summarized below: 
Table 2

Effect of Cold storage on strength

\begin{tabular}{|c|c|c|c|c|c|c|c|c|}
\hline \multirow{2}{*}{ Cement } & \multirow{2}{*}{ Mix } & \multirow{2}{*}{$\begin{array}{l}\text { Temper- } \\
\text { ature of } \\
\text { storage } \\
\text { water, } \\
\text { deg. F. }\end{array}$} & \multirow{2}{*}{$\begin{array}{l}\text { Storage } \\
\text { method }\end{array}$} & \multicolumn{2}{|c|}{$\begin{array}{l}\text { Strength, pounds } \\
\text { per square inch }\end{array}$} & \multicolumn{2}{|c|}{ Per cent of loss } & \multirow{2}{*}{$\begin{array}{l}\text { Number of } \\
\text { specimens }\end{array}$} \\
\hline & & & & 7 days & 28 days & 7 days & 28 days & \\
\hline $\mathrm{X}$ & Neat & $\begin{array}{l}60 \\
43 \\
42 \\
60 \\
34\end{array}$ & $\begin{array}{c}\text { Normal } \\
1 \\
2 \\
\text { Normal } \\
3\end{array}$ & $\begin{array}{l}735 \\
606 \\
654 \\
702 \\
638\end{array}$ & $\begin{array}{l}739 \\
693 \\
735 \\
745 \\
665\end{array}$ & $\begin{array}{r}0 \\
18 \\
11 \\
0 \\
9\end{array}$ & $\begin{array}{r}0 \\
6 \\
0 \\
0 \\
11\end{array}$ & $\begin{array}{l}10-12 \\
12-12 \\
12-12 \\
24-24 \\
24-23\end{array}$ \\
\hline $\mathrm{X}$ & $1: 3$ & $\begin{array}{l}60 \\
43 \\
42 \\
60 \\
34\end{array}$ & $\begin{array}{c}\text { Normal } \\
1 \\
2 \\
\text { Normal } \\
3\end{array}$ & $\begin{array}{l}300 \\
281 \\
283 \\
313 \\
262\end{array}$ & $\begin{array}{l}361 \\
361 \\
371 \\
408 \\
312\end{array}$ & $\begin{array}{r}0 \\
6 \\
6 \\
0 \\
16\end{array}$ & $\begin{array}{r}0 \\
0 \\
+3 \\
0 \\
24\end{array}$ & $\begin{array}{l}11-12 \\
11-11 \\
11-11 \\
24-24 \\
22-24\end{array}$ \\
\hline$Y$ & Neat & $\begin{array}{l}60 \\
43 \\
44 \\
60 \\
34\end{array}$ & $\begin{array}{c}\text { Normal } \\
1 \\
2 \\
\text { Normal } \\
3\end{array}$ & $\begin{array}{l}628 \\
650 \\
649 \\
628 \\
530\end{array}$ & $\begin{array}{l}843 \\
770 \\
872 \\
697 \\
622\end{array}$ & $\begin{array}{r}0 \\
+3 \\
+3 \\
0 \\
16\end{array}$ & $\begin{array}{r}0 \\
9 \\
+4 \\
0 \\
11\end{array}$ & $\begin{array}{l}12-12 \\
12-12 \\
12-12 \\
24-24 \\
22-24\end{array}$ \\
\hline Y & $1: 3$ & $\begin{array}{l}60 \\
43 \\
44 \\
60 \\
34\end{array}$ & $\begin{array}{c}\text { Normal } \\
1 \\
2 \\
\text { Normal } \\
3\end{array}$ & $\begin{array}{l}250 \\
253 \\
287 \\
228 \\
197\end{array}$ & $\begin{array}{l}350 \\
370 \\
327 \\
317 \\
234\end{array}$ & $\begin{array}{r}0 \\
+1 \\
+15 \\
0 \\
14\end{array}$ & $\begin{array}{r}0 \\
+6 \\
+7 \\
0 \\
26\end{array}$ & $\begin{array}{l}12-12 \\
12-11 \\
12-12 \\
22-24 \\
22-24\end{array}$ \\
\hline
\end{tabular}

From these results, it is safe to conclude that, aside from the effects of frost, low temperatures are adverse to the development of the hardening process in cement, and that in general this effect is more pronounced in mortars than in neat cement.

The adsorption of calcium hydroxide by the complex hydrogel may proceed at a lower rate at lower temperatures; or if this is not so, the primary hydration, of which this hydrogel is the product, may proceed more slowly, and thus less of the hydrogel be produced,-either of which processes will detract from the hydraulic activities of the mass. It would seem from the experiments that the latter is the more satisfactory explanation, since the test specimens which were chilled at first and allowed to return to normal temperature show a tendency to return to normal strength at the longer periods, while the general tendency in the series kept constantly in cold water is to fall further off from the normal, indi(ating only a limited arailable amount of hydrogel to undergo the coagulating process. 
The effect of sudden chilling at a period when a large proportion of the strength is already developed does not show any decided direction, both the positive and negative rariations from the normal areraging the same. It may therefore be concluded that, for the temperatures studied, a chilling of this kind has no significant effect.

An explanation according to the crystallization theory of hardening would fail to fit the facts so satisfactorily. In the specimens that were chilled at first and allowed to return to normal temperature, there should be under this hypothesis a more significant decrease of strength, owing to the formation of small, non-cohesive crystals from the rapid temperature change. The return to normal conditions should not favor so nearly complete a recuperation as has been noted; unless a re-solution of the crystals and recrystallization were supposed, in which case it may be argued that such a process would require an abnormal solubility of small crystals when compared with large. In a normal specimen, re-solution and recrystallization are undoubtedly going on, strengthening the structure, and the large crystals are growing at the expense of the small. If small crystals preponderate at seren days' age, resulting in a weak mass, it is necessary to postulate a comparatively high solubility of the small crystals in order to arrive at a normal strength at 28 days. This, while by no means impossible, is not probable.

Turning to the specimens kept continuously in cold water, it would seem that, although the first chilling should show severe effects, as it did, there should not be such a falling off in the rate of hardening, if the crystallization be progressive. It is quite possible, howerer, that crystallization at this temperature is not favored, and that the total number of binding crystals of calcium hydroxide is therefore less than at normal temperatures.

\section{QUANTITY OF WATER AT FIRST ADDED}

Size of cement particles.-Other factors being equal, the amount of cement rendered inert by the action of water is proportional to the percentage of fine particles. This is an absolute condition and presupposes free access of water to every particle. Teedless to say, in practice this condition is seldom realized, except approximately in laying concrete under water, or in the careless use of an excess of water in mixing, or in protracted mixing.

In the use of a very fine cement, then, if the proper proportion of water is added, the mixing time carefully regulated and proper precautions taken in depositing, the influence of texture upon the strength of the mass occasioned by the action of water is reduced to a small quantity, 
by virtue of the greater hydraulic activity of the fine particles, increasing the impermeability, as will be shown, and the confining therefore of the action of the excess water to a narrow zone. The bulk of the cement will be properly hydrated in spite of. the fineness.

The investigation of the effect of the size of particles due to the action of water thereon alone is not feasible, because no satisfactory measure of laitance formation, except the strength of the mass, has been devised. The measure of the strength would be imsatisfactory, since the proportion of fine particles affects the strength in other ways than through the formation of laitance, as has been pointed out in a previons communication.

From a study of the hydraulic properties of reground cement, Spackmann and Lesley conclude (93) that only the very fine flour in cement, that portion not measured by the present tests using sicres, reacts when gaged with water and gives strength. It is difficult, of conrse, to draw a sharp dividing line between active and inactive material in cement, although it must be admitted that the greater part of the coarse material, eren though it be of the same chemical composition as the fine, has little or no cementing value and serves mainly as a filler.

Suitable fractional separation of the portion of cement passing the 200 sieve, by air-elutriation or other method, shonld with careful study be a valuable guide to the most efficient mechanical composition. Experiments upon the first methor of separation are recorded by Peterson (i1), and a scientific method of fractional elutriation using an inactive liquid has been worked out by 'Thompson (100). Mnch should be gained by the application and development of these methods. 'The influence of the size of particles of inert material added to the cement is also of great consequence, and a proper merhanical grading of the sand used in mortars is recognized as vital. The presence of clay in this sand, or the addition of clay alone to cement, come under this category, and have occasioned a great deal of discussion (8, 32, 33, 110).

A comparison was made of the permeability of $1: 4$ mortar of Portland cement, when used in its ordinary condition, and when screened throngh a number 200 sieve. 
TABLE 3

Permeability of S-inch C'ubes, Age 28 Days, Subjected to 80 lbs. Pressure

\begin{tabular}{|c|c|c|c|c|}
\hline \multirow{2}{*}{ Cement } & \multirow{2}{*}{$\begin{array}{c}\text { Temperature } \\
\text { of water. } \\
\text { Deg. Fahrenheit }\end{array}$} & \multicolumn{2}{|c|}{$\begin{array}{c}\text { Grams of water passing } \\
\text { per hour }\end{array}$} & \multirow{2}{*}{$\begin{array}{c}\text { Number of } \\
\text { testy }\end{array}$} \\
\hline & & Unscreened & Screened & \\
\hline A. & $66 \quad 68$ & 22 & 33 & \multirow{10}{*}{$\begin{array}{l}5,6 \\
6,6 \\
6,6 \\
5,6 \\
5,6 \\
6,6 \\
3,6 \\
5,6 \\
6,6\end{array}$} \\
\hline B... & $68 \quad 68$ & 25 & 2 & \\
\hline$C \ldots \ldots \ldots \ldots$ & $68 \quad 68$ & 29 & Trace & \\
\hline$D \ldots \ldots \ldots \ldots$ & $68 \quad 68$ & 331 & 81 & \\
\hline $\mathrm{E} \ldots \ldots \ldots \ldots \ldots$ & $64 \quad 64$ & 27 & Trace & \\
\hline $\mathrm{F} \ldots \ldots \ldots \ldots$ & $64 \quad 64$ & 31 & 2 & \\
\hline$G \ldots \ldots \ldots \ldots$ & $64 \quad 64$ & 5 & 0 & \\
\hline$H \ldots \ldots \ldots \ldots$ & $68 \quad 72$ & 6 & Trace & \\
\hline$I \ldots \ldots \ldots \ldots \ldots$ & $68 \quad 68$ & 71 & 0 & \\
\hline Average.... & . & 61 & 13 & \\
\hline
\end{tabular}

The marked decrease in permeability resulting from the nse of finer rement in mortar demonstrates that in impermeability, as in strength. the finest particles are the most active factors.

Mechanical agitation when nater is added.-Increased working should weaken a cement after a certain maximum point is passed. In order to establish this point, the effect of prolonged working was investigated. It was necessary to use a mix of fluid consistency, in which, for obvious reasons, the final set would not under normal conditions take place during the time over which the experiments were extended.

Two grouts were employed: one in which cement was mixed with jo per cent of its weight of water, and one in which an equal weight of water was used. The different tests were run respectively for periods from one mimute to five hours, and they were mixed in a motor-driven stirring machine of the type common in chemical laboratories.

After the stated period of stirring, the grouts were poured into glass tubes and kept in a lamp closet for the twenty-eight-day period. Cylinders exactly two diameters high were cut from the specimens and crushed in the compressing machine, two cylinders being erushed for each period, and the average of the compressive strengths being recorterl. 
Table 4

Tuenty-eight-day Tests of Grouts Mixed for Tarying Lengths of Time

\begin{tabular}{|c|c|c|}
\hline \multirow{2}{*}{ Duration of mixing } & \multicolumn{2}{|c|}{$\begin{array}{c}\text { Compressive strength, pounds } \\
\text { per square inch, average } \\
\text { of duplicate tests }\end{array}$} \\
\hline & 50) perct grout & 100 per ct.grout \\
\hline 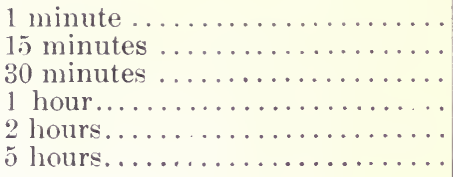 & $\begin{array}{l}5240 \\
5545 \\
5710 \\
5875 \\
6075 \\
4775\end{array}$ & $\begin{array}{l}3095 \\
4725 \\
4955 \\
4840 \\
4320 \\
4538\end{array}$ \\
\hline
\end{tabular}

The effect of mechanical agitation, when thus prolonged, is equivalent to that of the use of excess water-the strength of the cement is progressively diminished as the working proceeds. It is noteworthy that the effect is only reached after a certain optimum period is passed. Before this time, increased working increases the strength. We may conclude that there occurs within this period a process which neutralizes the effect of hydrolysis; and this process is probably the formation of the network which constitutes the setting.

As will be seen later, the effect of excess water is to recluce the ultimate strength. The effect, then, of mechanical agitation must be to bring more cement into contact with water and, therefore, to increase hydrolysis. This is probably accomplished by stripping off the protective film of gelatinous material which envelops each cement particle when it comes into contact with water, which film regulates the hydration of cement and causes it to proceed in a regular manner. This film being stripped off, the cement is subject to the destructive action of hydrolysis.

Where more water is originally present, the lestructive action is sooner attained, as will be seen by comparing the 100 per cent grout with the 50 per cent. Evidently, the setting process proceeds best at high concentrations, when the amount of water is low. This may be so regulated that the setting process will not take place at all, by nsing a large excess of water and much mechanical agitation, as has been repeatedly observed. by the writer.

setting time of cement in Taboratory air and in damp closet.-The standard specifications for setting-time tests call for storing the specimen in the lamp closet, whereas the tests as generally conducted in most laboratories are made in the open laboratory air. A series of experiments was made, for the purpose of noting the deriation from standart results caused by this departure from the rule. 
TABLE כ̄

Setting Time in Laboratory Air and in Damp Closet

\begin{tabular}{|c|c|c|c|c|}
\hline \multirow{3}{*}{ Cement } & \multicolumn{4}{|c|}{ Time of set in minutes } \\
\hline & \multicolumn{2}{|c|}{ Laboratory air } & \multicolumn{2}{|c|}{ I)amp closet } \\
\hline & Initial & Final & Initial & Final \\
\hline 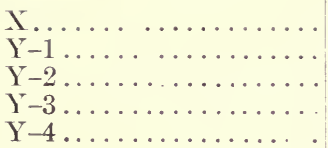 & $\begin{array}{l}255 \\
120 \\
300 \\
240 \\
240\end{array}$ & $\begin{array}{l}375 \\
360 \\
420 \\
360 \\
390\end{array}$ & $\begin{array}{l}300 \\
300 \\
360 \\
285 \\
250\end{array}$ & $\begin{array}{l}435 \\
450 \\
480 \\
420 \\
450\end{array}$ \\
\hline
\end{tabular}

From these results, it will be seen that setting in a relatively dry atmosphere takes place in a shorter time than in a damp one; also that the setting time is more uniform under conditions of high atmospheric humidity.

At the same temperature, evaporation takes place more rapidly in the former case; and allowing a cement mix to stand in such a position that evaporation of the mixing water may readily take place is practically equivalent to the use of an insufficient amount of mixing water.

Effect of excess of mixing water on strength of concrete.-Concrete is often mixed so wet that, as it is filled into forms to a depth of sereral feet, the water rises above the concrete and throws out considerable laitance from the cement. The ease of mixing and placing rery wet concrete is the constant incentive for its use. This practice, however, is followed by a great deal of deterioration of the concrete in strength.

The strength rapidly decreases with the increase in the quantity of water used in mixing. The visible effect of this weakening is the formation of laitance, which has little or no setting power or strength, and which represents the loss of an active part of the cement, since, as is lecognized, the finer parts are more hydraulically active.

Tests were made by mixing concrete at normal consistency and shoveling one-half the batch into a tank containing three to four inches of water, the depth of concrete being about four inches. 'The water rose to about an equal depth above the concrete. In test No. 1, the concrete was allowed to settle in water four inches in depth for 30 mimutes, when the excess of water was siphoned off and the remaining material poured into molds. In test No. 2, the depth of water in the tank was three inches, and the water was siphoned off immediately while in agitation. In test No. 3, the same process was repeated, except that the depth of the water 
was four inches, and the concrete used was somewhat leaner. Test No. 4 represents the direct qualitative effect of the addition of an excess quantity of mixing water without subsequent handling. All specimens were cylinders six inches in diameter and 12 inches high. The remainder of the batch of concrete in each case was poured directly into molds, and the specimens were broken at 28 days. The amount of cement lost was roughly ascertained where possible by filtering the siphoned water and weighing the amount retained on the filter.

Table 6

Effect of Excess of Mixing Water on Strength of Concrete

\begin{tabular}{|c|c|c|c|c|c|}
\hline Test No. & $\begin{array}{c}\text { No. of } \\
\text { specimens }\end{array}$ & Proportions & $\begin{array}{l}\text { Per cent } \\
\text { of water }\end{array}$ & $\begin{array}{c}\text { Strength at } 28 \\
\text { days, pounds } \\
\text { per sq. in. }\end{array}$ & $\begin{array}{l}\text { Per cent of } \\
\text { cement lost }\end{array}$ \\
\hline $\begin{array}{l}1 \\
1^{5}\end{array}$ & $\begin{array}{l}3 \\
2\end{array}$ & $\begin{array}{l}1: 2: 4 \\
1: 2: 4\end{array}$ & $\begin{array}{l}8.2 \\
8.2\end{array}$ & $\begin{array}{r}1240 \\
760\end{array}$ & .. \\
\hline $\begin{array}{l}2 \\
2^{5}\end{array}$ & $\begin{array}{l}3 \\
2\end{array}$ & $\begin{array}{l}1: 2: 4 \\
1: 2: 4\end{array}$ & $\begin{array}{l}8.2 \\
8.2\end{array}$ & $\begin{array}{r}1485 \\
770\end{array}$ & 10 \\
\hline $\begin{array}{l}3 \\
3^{5}\end{array}$ & $\begin{array}{l}3 \\
3\end{array}$ & $\begin{array}{l}1: 2.33: 5 \\
1: 2.33: 5\end{array}$ & $\begin{array}{l}8.2 \\
8.2\end{array}$ & $\begin{array}{r}1490 \\
315\end{array}$ & 12 \\
\hline $\begin{array}{l}4 \\
4\end{array}$ & $\begin{array}{l}3 \\
3\end{array}$ & $\begin{array}{l}1: 2: 4 \\
1: 2: 4\end{array}$ & $\begin{array}{r}8.2 \\
10.3\end{array}$ & $\begin{array}{l}1385 \\
1155\end{array}$ & $\begin{array}{l}. \\
.\end{array}$ \\
\hline
\end{tabular}

5 Specimens shoveled into water as described.

Evidently, then, the mere presence of an excess of water is sufficient to produce the weakening effect, independently of any actual removal of cement from the concrete. As may be seen from Nos. 1 to 3, the leaner mixes suffer the greater deterioration in strength.

Effect of excess of mixing water on permeability of concrete.-A parallel series of tests upon the permeability of concrete treated with an excess of water was made, in which the correspondingly numbered specimens were treated in the same manner. The cylinders cast from these batches were eight inches in diameter and six inches in length, and were cased in the standard manner for permeability tests. Three specimens were made for each test, and at the age of 28 days were submitted first to 40 pounds pressure for one hour, then to 80 pounds for one hour, without interruption. The flow recorded is in grams passing during the last ten minutes of test. 
Table $\tau$

Effect of Excess of Mixing Water on Permeability of Concrete

\begin{tabular}{|c|c|c|c|c|c|c|}
\hline \multirow{2}{*}{ Test No. } & \multirow{2}{*}{\multicolumn{2}{|c|}{ Proportions }} & \multirow{2}{*}{$\begin{array}{l}\text { Per cent of } \\
\text { water }\end{array}$} & \multirow{2}{*}{$\begin{array}{c}\text { Temperature } \\
\text { of percolating } \\
\text { water }\end{array}$} & \multicolumn{2}{|c|}{$\begin{array}{c}\text { Grams passing in last } \\
\text { ten minutes }\end{array}$} \\
\hline & & & & & 40 pounds & 80 pounds \\
\hline $\begin{array}{l}1 \\
1^{6}\end{array}$ & $\begin{array}{l}1: 2 \\
1: 2\end{array}$ & $\begin{array}{l}: 4 \\
: 4\end{array}$ & $\begin{array}{l}8.2 \\
8.2\end{array}$ & $\begin{array}{l}67^{\circ} \mathrm{F} . \\
\cdots \cdots\end{array}$ & $\begin{array}{r}0 \\
479\end{array}$ & $\begin{array}{r}0 \\
456\end{array}$ \\
\hline $\begin{array}{l}2 \\
2^{6}\end{array}$ & $\begin{array}{l}1: 2 \\
1: 2\end{array}$ & & $\begin{array}{l}8.2 \\
8.2\end{array}$ & $\begin{array}{l}58^{\circ} \mathrm{F} . \\
\ldots \ldots\end{array}$ & $\begin{array}{r}0 \\
212\end{array}$ & $\begin{array}{r}0 \\
588\end{array}$ \\
\hline $\begin{array}{l}3 \\
3^{6}\end{array}$ & $\begin{array}{l}1: 2 \\
1: 2\end{array}$ & $\begin{array}{l}: 5 \\
: 5\end{array}$ & $\begin{array}{l}8.2 \\
8.2\end{array}$ & $\begin{array}{l}56^{\circ} \mathrm{F} . \\
60^{\circ} \mathrm{F} .\end{array}$ & $\begin{array}{r}0 \\
1814\end{array}$ & $\begin{array}{l}21 \\
\text { Not tested }\end{array}$ \\
\hline $\begin{array}{l}4 \\
4\end{array}$ & $\begin{array}{l}1: 2 \\
1: 2\end{array}$ & $\begin{array}{l}: 4 \\
: 4\end{array}$ & $\begin{array}{r}8.2 \\
10.3\end{array}$ & $\begin{array}{l}67^{\circ} \mathrm{F} . \\
\ldots \ldots\end{array}$ & $\begin{array}{l}38 \\
26\end{array}$ & $\begin{array}{l}18 \\
80\end{array}$ \\
\hline
\end{tabular}

${ }^{6}$ Specimens shoveled into water as described above.

In the foregoing experiments, the decrease in strength and watertightness may be referred to the deteriorating influence of excess water upon the cement (16). It may of course be argued that the more marked effects obtained in series 1,2 and 3 than in series 4 are due to the method of making the tests; that is, that a considerable proportion of the active cement was actually removed from the body of the concrete by siphoning off the supernatant water with its laitance.

Effect of excess of mixing water on the strength of neat cement.With the idea in mind that the weakening effect was independent of the removal of cement (1), a further series of tests was instituted, using a neat cement of good quality. The cement was poured into a series of glass tubes in which increasing proportions of water had been put, the tests representing a series of grouts mixed respectively with 50, 75,100 , 150,200 and 500 per cent by weight of cement of water. The tubes were shaken for one hour and then allowed to stand for 28 days. The cement settled into the bottom of the tubes in the order of its coarseness, the fine nebulous laitance settling last as a cheesy white layer of increasing thickness, as the percentage of water was higher. This layer was carefully trimmed off in preparing the test specimens.

On breaking out the cylinders from the tubes at the end of the test period, it was decided to cut each cylinder into two, each exactly one diameter high, carefully noting the respective position of each in the tube. On submitting these to compression it was seen that the direction of difference between the upper and lower layers was not constant, nor 
was the difference a significant one, so that it was considered legitimate to average the strengths.

It will be seen by the table below that, even without actual removal of any cement, the formation of laitance has a weakening action upon cement.

\section{TABLE 8}

Compressive Strength of Grouts Mixed with Tarying Proportions of Water

\begin{tabular}{|c|c|}
\hline Per cent of water & $\begin{array}{c}\text { Crushing strength, } \\
\text { lbs. per square inch, } \\
\text { average of two tests. } \\
\text { Age, 28 days }\end{array}$ \\
\hline 50 & 6855 \\
75 & 5900 \\
100 & 4500 \\
150 & 3430 \\
200 & 2960 \\
500 & 1810 \\
\hline
\end{tabular}

The effect of excess of mixing water is therefore seen to result in decrease of strength as the water increases. Whether the effect is a permanent one was the next question that presented itself. To settle this point, a new series was undertaken, in which a larger number of differing percentages was introduced, and in which the resulting strength at two periods was determined.

The cement was mixed with the stated percentage of water, and worked for two minutes, the drier mixes upon the table in the usual fashion, and the wetter mixes merely poured into the tubes and shaken. Paper mailing tubes were used, 2 inches by 48 inches, treated with molten paraffin and sealed with paraffined corks, so as to be absolutely tight. To obviate the effect of possible leakage, the whole series was stored in damp sand.

Cylinders two diameters high were cut from the specimens at the stated periods, each cylinder being cut as nearly as possible the same distance from the bottom, and care was taken to aroid including any of the soft cheesy top portion, the settled laitance. 
TABLe 9

Compressice Strength of Grouts Mixed with Valying Proportions of Water, Over Extended Period

(Each result is the average strength of three specimens.)

\begin{tabular}{|c|c|c|c|}
\hline \multirow{2}{*}{$\begin{array}{c}\text { Percentage of } \\
\text { water }\end{array}$} & \multicolumn{2}{|c|}{$\begin{array}{c}\text { Compressive strength, pounds per } \\
\text { square inch }\end{array}$} & $\begin{array}{c}\text { Per cent gain in } \\
\text { strength over } \\
\text { 28 days }\end{array}$ \\
\cline { 2 - 4 } & 28 days & 3 months & \\
\hline & 7076 & 7504 & 6 \\
22 & 6174 & 5402 & 32 \\
25 & 4563 & 6030 & 27 \\
30 & 3992 & 5059 & 77 \\
38 & 2991 & 5312 & 93 \\
50 & 2113 & 4078 & 120 \\
75 & 1609 & 3544 & 87 \\
100 & 1270 & 2379 & 97 \\
150 & 1306 & 2579 & 186 \\
200 & 399 & 1141 & \\
500 & & & \\
\hline
\end{tabular}

It is apparent from these figures that the effect of hydrolysis upon the strength of cement is a reversible one, at least to a certain extent, since the specimens in which an excess of water was used in mixing showed a greater recuperative ability at the longer period than the cement in which the normal amount of mixing water, in this case $2 \%$ per cent, was used.

Upon inspection, it was observed that the three months' specimens showed in each case much less laitance than the similar 28 days' specimens had shown, and it was considered probable that the laitance, in standing, had adsorbed free lime from the remainder of the cement, through the activity of the water permeating the mass, and thus reverted to the original condition of the cement, or an approach thereto. An analysis was accordingly made of laitance scraped off from the top of one of the 500 per cent water specimens and thoroughly washed by decantation. It probably represents a maximum condition in the hydrolysis of cement.

TABLE 10

Analysis of Laitance from 500 per cent specimen

\begin{tabular}{|c|c|c|}
\hline & $\begin{array}{c}\text { As obtained from } \\
\text { specimen }\end{array}$ & $\begin{array}{c}\text { Treated with } \operatorname{lime} \\
\text { water }\end{array}$ \\
\hline 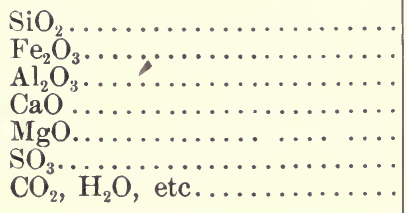 & $\begin{array}{r}15.28 \\
2.28 \\
3.98 \\
26.96 \\
2.86 \\
6.47 \\
42.17\end{array}$ & $\begin{array}{r}15.91 \\
2.42 \\
5.82 \\
36.67 \\
1.28 \\
2.72 \\
35.18\end{array}$ \\
\hline
\end{tabular}


The normal ratio of silica to lime in unset cement may be considered 1 to 2.82. In this material we find the ratio 1 to 1.76 . This indicates a great loss of lime; and it was thought possible, that, by adsorption of lime, this laitance might regain at least a part of its hydraulic properties. Accordingly it was digested for several days with lime water at laboratory temperature, filtered off, carefully washed with distilled water and dried, as was the previous sample, at $100^{\circ} \mathrm{C}$. An analysis showed the results tabulated in the second column. The ratio of $\mathrm{SiO}_{2}$ to $\mathrm{CaO}$ had changed to $1: 2.30$.

Besides direct metathetical reactions between the components of cement and the water solution which always surrounds a mass of hardening cement, adsorption of various materials from this solution is unquestionably always going on. Were the fine particles of cement inert chemically, this would still take place, by virtue of the enormous total surface which they must present. Clay, it has been demonstrated, has the property of adsorbing ions of $\mathrm{CO}_{3}$ from solutions of carbonates, and of $\mathrm{Cl}$ from solutions of chlorides (10).

The laitance then may, by adsorption of calcium hydroxide given off from the cement adjacent to it, recover some of the lime lost by it. Whether the lime adsorbed restores the original status of constitution is of course mere speculation. The trend of the strength tests shows that this is probably not so, but that the adsorption is not entirely a reversion of the hydrolytic reaction; in other words, that "drowned" cement will probably never recover and attain to the strength it would have had with proper hydration.

Effect of the presence of clay and dissolved substances.-It is apparent that if the decreased strength be directly referable to the action of the excess water upon the cement, any means of preventing the access of excess water should prevent, if only to a degree, the destructive action. The colloidal nature of clay (6) has been utilized in the water-proofing of concrete, the principle of its action being the formation of continuous gelatinous films throughout the structure, which prevent the passage of water. Although the same problem is not presented in a grout that exists in finished concrete, it is probable that some blanketing action might occur upon the addition of clay to the mixed mass.

The point was investigated. To correct for the effect of absorption of part of the mixing water by the admixed clay, a consistency test was made upon a sample of cement to which 10 per cent of clay had been added, and it was found to require 4 per cent more water than the same cement used neat.

The clay mixes were accordingly gaged with 4 per cent more water 
than the corresponding neat cement mixes, and the following series of compressive tests was made:

TABLE 11

Effect of Clay upon Destructive Action of Exeess of Mixing Water (Average of two tests at 28 days)

\begin{tabular}{|c|c|c|c|}
\hline \multicolumn{2}{|c|}{ Neat cement } & \multicolumn{2}{|c|}{$\begin{array}{l}\text { Cement, } 10 \text { per cent of which was } \\
\text { replaced by a fat clay (dried) }\end{array}$} \\
\hline $\begin{array}{l}\text { Water, } \\
\text { per cent }\end{array}$ & $\begin{array}{l}\text { Compressive } \\
\text { strength, pounds } \\
\text { per square inch }\end{array}$ & $\begin{array}{l}\text { Water, } \\
\text { per cent }\end{array}$ & $\begin{array}{l}\text { Compressive } \\
\text { strength, pounds } \\
\text { per square inch }\end{array}$ \\
\hline $\begin{array}{r}50 \\
75 \\
100 \\
150 \\
200 \\
500\end{array}$ & $\begin{array}{r}5782 \\
3134 \\
2273 \\
1896 \\
1381 \\
514\end{array}$ & $\begin{array}{r}54 \\
79 \\
104 \\
154 \\
204 \\
504\end{array}$ & $\begin{array}{c}1282 \\
1328 \\
2577 \\
2156 \\
1320 \\
\text { No strength } \\
\text { developed }\end{array}$ \\
\hline
\end{tabular}

If the action of saline solutions upon cement is to accelerate the hydrolysis of the latter, it would appear that the destructive action of excess water would be accelerated by the presence therein of saline substances in solution; also, it is legitimate to expect that the addition of clay restraining the hydrolysis due to excess water will in this case exert a. similar influence.

The following experiments, parallel to the foregoing ones, elaborate this point:

\section{TABLE 12}

Effect of Clay upon accelerated destruetive Action of Wixing Water Containing 5 per cent of Magnesium Sulphate

(Arerage of two tests at 28 days)

\begin{tabular}{|c|c|c|c|}
\hline \multicolumn{2}{|c|}{ Neat cement } & \multicolumn{2}{|c|}{$\begin{array}{l}\text { Cement, } 10 \text { per cent of which was } \\
\text { replaced by a fat clay (dried) }\end{array}$} \\
\hline $\begin{array}{l}5 \text { per cent solution } \\
\text { of magnesium } \\
\text { sulphate, } \\
\text { per cent }\end{array}$ & $\begin{array}{l}\text { Compressive } \\
\text { strength, pounds } \\
\text { per square } \\
\text { inch }\end{array}$ & $\begin{array}{c}5 \text { percent solution } \\
\text { of magnesium } \\
\text { sulphate, } \\
\text { per cent }\end{array}$ & $\begin{array}{l}\text { Compressive } \\
\text { strength, pounds } \\
\text { per square } \\
\text { inch }\end{array}$ \\
\hline 50 & 2196 & 54 & 2774 \\
\hline 75 & 548 & 79 & 1608 \\
\hline 100 & 1512 & 104 & No strength \\
\hline 150 & 556 & 154 & $66 \quad 66$ \\
\hline 200 & No strength & 204 & " \\
\hline 500 & No strength & 504 & "6 \\
\hline
\end{tabular}


From these two series of experiments, it is qualitatively apparent that the presence of clay does prevent a certain amount of hydrolysis. From the first series, it is seen that this effect only begins to show itself as higher percentages of water are present, which would indicate that the clay may have taken up much more water than the constituency test revealed, and that, in the relatively drier mixes with clay, the cement suffered in strength because of insufficient water. On the other hand, experiments at this laboratory in which clay was used, replacing up to 10 per cent of cement in normally gaged material, showed that no significant decrease in strength was thereby obtained; hence the loss in strength in the 54 and 79 per cent grouts cannot be due to this cause.

It is more probable that the colloidal nature of the added clay is brought into play more effectively at the concentrations in which increased strength is observed, and that the latter is due to the coagulation of the clay by electrolytes adsorbed at this optimum concentration.

The same result would obtain where additional saline material has been added to the mixing water, as in the series where a 5 per cent solution of magnesium sulphate was used. The clay here prevents the acceleration of hydrolysis by the magnesium sulphate through adsorption of part thereof, and possibly by coagulating, forming an impenetrable barrier to the further action of water upon the remainder of the cement.

\section{QLANTTTY OF WATER THAT MAY SUBSEQUENTLY CONE IXTO CONTACT}

WITH THE SYSTEM

Permeability.-The solvent effect of water coming into contact with cement structures is best studied by the permeability test. 'This consists in forcing water through a mortar or concrete at a known pressure and observing the amount of leakage through the specimen. In detail, the specimen is generally made up in the form of a cylinder, and this is cased with a thick coating of neat cement on all sides but the bottom. The water, under pressure, is applied on the full cross-section of the specimen and forced through, dripping from the bottom, whence it may be collected.

With neat cement, of course, this method is inapplicable, becanse of the density of the material and the consequently enormous pressure necessary to force water through it, and moreover because of the mechanical difficulty in confining the water strictly to a passage through the specimen. The specimens tested, then, are lean mortars and concretes.

Although this test is designed to ascertain the resistance which these materials offer to the flow of water, it is evident that this resistance is not a constant quantity in the case under consideration. 
The temperature and pressure of the percolating water being constant, the flow is diminished by cementing and clogging, and increased by erosion and solution; the quantity of water flowing through the mortar or concrete therefore is a function of the balancing of these processes.

Cementing may result from deposition of material originally in solution in the percolating water, or dissolved from one portion of the structure and deposited in another.

Clogging, similarly, results from material originally in suspension in the percolating water, and deposited in the pores of the concrete, or from material eroded from one part of the mass, either mechanically or as a result of solution of the attacking portions, and deposited in another part.

Erosion per se is a negligible factor; that is, the flow of pure water, carrying no suspended matter, will have very small mechanical effect upon an insoluble material. When the water is armed with suspended matter, however, its corrasive effects become proportionally magnified.

Solution is the most important factor in the process of percolation. Following the order laid down by Tan Hise for matural rocks (10t, p. 536 ), the basic materials removed are, firstly, the alkalies and, secondly, the alkaline earths, in the order calcium, magnesium. Since the alkalies exist in cement in the proportion of a little over one per cent and are not essential to the hydraulic properties or the strength, their solution is a matter of little consequence. except in that it may result in the formation of solutions which react upon the lime compounds and render their solution more easy of accomplishment. This reaction has been considered elsewhere. The removal of magnesium compounds proceeds at a lesser rate, although there is a greater percentage of them present; and their removal, in the main, may be dismissed as insignificant.

Since more than half the weight of fresh cement consists of lime, and since the strength of cement depends for the greater part upon calcium hydroxide, whether crystalline or adsorbed by colloids, the removal of calcium hydroxide from set cement is the factor of the greatest importance. Considering its solubility in pure water, the reversion of the hydroxide to the crystalline form tends to diminish its solubility, or from the other standpoint, its adsorption by a colloid tends to remove it from the solvent action of water. Unfortunately, however, it must be borne in mind that without exception, cement structures are nowhere subject to the action of pure water alone. From rain water, with its appreciable burden of dissolved gases and atmospheric salts, to the water of the ocean and the more heavily laden rock and mine waters, concrete structures are everywhere in contact with saline solutions of varying concentrations. 
The effect of solution in percolation, then, is to a small degree dependent upon the solubility of the components in pure water. This effect diminishes as time goes on, because of the reversion of the soluble material to a less soluble form and because of the protection afforded by the insoluble portions of the system decreasing the exposed area of soluble material. The washing away of these protecting films will of course neutralize the second factor. The increased solubility of the components of set cement in solutions of various electrolytes is the more important element in percolation. Even a very dilute solution may have tremendous total solvent power, when the time element is considered. In fact, it may be that the action of a dilute solution will on the whole exceed that of a concentrated solution, by reason of the greater cementing and choking action of the latter, tending to diminish the quantity of water that may come into contact with the soluble portions. A dilute solution, therefore, with its more insidious attack, is probably more to be feared in the end than the strong brine.

Observation of the behavior of concretes and mortars during the permeability tests gives a clue to the balancing of these processes, whether there is a preponderance of cementing and clogging on the one hand, or of solution and erosion on the other. Attempts were made, in the experiments noted below, to study chemically the reactions involved, by periodical analyses of the percolating water. To this end nearly four hundred complete analyses of the effluent water were made. Upon tabulation of these it was observed that any deductions based upon them would be inconclusire, as the chemical composition of the effluent water represented one of a great number of variable factors that might occur at any point either within or without the concrete. The single qualitative generalization, that lime was removed from the cement at a diminishing rate, is the only permissible conclusion from the analytical data.

The original purpose of these tests was to ascertain the suitability of rarious aggregates for use in concrete, with reference to their stability in the presence of percolating water. At the conclusion of the series, it was found that the effect of water upon the various aggregates was practically negligible, during the period of obserration, and that the action had been confined to the cement of the mortar. The aggregates had been protected from the action of water by the cement, it being probable, however, that a continuation of the tests would have revealed the action of water upon these rocks, when the protective influence was remored.

A series of sixteen aggregates was used, in as many concrete specimens. Since it is not the purpose of this report to discuss the relative suitability of these materials for concrete construction, but only to consider 
the action of the water upon the cement, two cases alone will be considered.

The rock was crushed and screened for each experiment to the same average effective size, corresponding to the following mechanical analysis:

TABLE 13

Mechanical Analysis of Aggregate used in Permeability Tests

\begin{tabular}{|c|c|c|}
\hline Sieve & $\begin{array}{c}\text { Square mesh } \\
\text { opening, in inches }\end{array}$ & Per cent passing \\
\hline $13 / 4$ & 1.89 & 100 \\
$11 / 2$ & 1.58 & 94 \\
1 & 1.02 & 59 \\
$3 / 4$ & .78 & 32 \\
$2 \frac{13}{2 / 3}$ & .59 & 21 \\
3 & .48 & 16 \\
4 & .30 & 6 \\
& .22 & 0 \\
\hline
\end{tabular}

The sieve ratings are based on diameters of spheres of equivalent volume to the largest sized stone particles that will pass.

The fine aggregate was crushed quartz, the standard sand formerly used for cement testing, passing the No. 20 and retained on the No. 30 sieve. The cement used was a standard Portland of high quality.

The specimens were made in the laboratory's standard form for permeability test, cylinders eight inches in diameter and six inches in length, the proportions used being $1: 3.5: 6$, this being found the richest mix practicable to secure the porosity required for the test. They were cased in neat cement, and connected suitably for subjection to the pressure of the city's water mains. Each specimen was protected from the direct flow of the water by a layer of one inch of clean coarse sand. The average pressure for the period of observation ( 52 weeks) was 22 pounds. The determinations of the rate of leakage were made weekly at first, and later erery two weeks until the end of the test.

The data appended below represent observations on the rate of percolation of water through two of the specimens which present the greatest interest from the standpoint of this paper, this flow being recorded in grams passing in ten minutes. The aggregate used in one specimen was a hardened neat cement, crushed to the size stated, and used in place of the rock generally employed in concrete. The parallel specimen selected for comparison was one in which the aggregate was a crushed granite, which showed a low solubility in hydrochloric acid (2.66 per cent dissolved in one hour's treatment with $1: 1 \mathrm{HCl}$ ). 
Temperature records of the percolating water were not kept, since these tests represent a part of a larger series in which this would have been impracticable. The other aggregates tested showed results from which it was quite difficult to draw any legitimate conclusions as to the relative suitability of different rocks in concrete subjected to these conditions.

Concretes containing different aggregates.-A series of tests on concretes made up of different aggregates but with the same cements gave results which may be tabulated as follows:

TABLe 14

Flow in Grams of Water passing in 10 Minutes through Concrete specimens subjected to continuous Water Pressure for 52 Weelis

\begin{tabular}{|c|c|c|c|c|c|}
\hline \multirow{2}{*}{\multicolumn{2}{|c|}{ Time }} & \multirow[b]{2}{*}{$\begin{array}{l}\text { Pressure, } \\
\text { pounds per } \\
\text { square inch }\end{array}$} & \multirow[b]{2}{*}{ Month } & \multicolumn{2}{|c|}{ Grams passing in 10 minutes } \\
\hline & & & & $\begin{array}{l}\text { Concrete with } \\
\text { aggregate of } \\
\text { crushed } \\
\text { hardened } \\
\text { neat cement }\end{array}$ & $\begin{array}{l}\text { Concrete with } \\
\text { aggregate } \\
\text { of erushed } \\
\text { granite }\end{array}$ \\
\hline \multicolumn{2}{|c|}{24 hours } & 25) & January... . & 2111 & 60 \\
\hline \multirow{3}{*}{\multicolumn{2}{|c|}{$\begin{array}{l}1 \text { week } \\
2 \text { weeks } \\
3\end{array}$}} & 22 & February .. & 836 & 31 \\
\hline & & 22 & & 662 & 26 \\
\hline & & 20 & & 626 & 40 \\
\hline & “" & 25 & & 570 & 60 \\
\hline & “6 & 22 & March... & 603 & 62 \\
\hline 6 & “، & 20 & & 530 & 50 \\
\hline 7 & “ & 20 & & 1295 & 38 \\
\hline & " & 25 & & 1127 & 40 \\
\hline 10 & “" & 25 & April...... & 1310 & 45 \\
\hline 12 & " & 26 & & 870 & 25 \\
\hline 14 & “ & 24 & Мay... & 997 & 36 \\
\hline 16 & “" & 24 & & 985 & 28 \\
\hline 18 & “" & 20 & June... . & 973 & 32 \\
\hline 20 & “" & 17 & & 639 & 20 \\
\hline 22 & " & 20 & & 792 & 40 \\
\hline 24 & “ & 17 & July... & 731 & 36 \\
\hline 26 & “" & 22 & & 802 & 43 \\
\hline 28 & “6 & 26 & August..... & 800 & 49 \\
\hline 30 & “ & 22 & & 781 & 46 \\
\hline 32 & " & 20 & September. & 763 & 50 \\
\hline 34 & “ & 19 & & 115 & Trace \\
\hline 36 & “ & 26 & October... & 105 & 2 \\
\hline 38 & $"$ & 26 & & 107 & 2 \\
\hline 40 & “" & 23 & November.. & 110 & 3 \\
\hline 42 & “" & 25 & & 93 & 2 \\
\hline 44 & “ & 22 & December.. & 75 & 5 \\
\hline 46 & “" & 21 & & 70 & 3 \\
\hline 48 & "“ & 25 & & 80 & 10 \\
\hline 50 & “ & 20 & January.... & 73 & 7 \\
\hline 52 & “" & 20 & & 78 & 7 \\
\hline
\end{tabular}


Comparison of these two sets of figures indicates that the cement of the concrete is more attacked than the aggregate. In fact, the flow obtained in this specimen was the highest but one of a series of sixteen, and the total lime content of the effluent water was also the highest but one.

The visible effect upon examination of the interior of the specimens was a bleaching of the mortar, with evident solution of the cement. The original percentage of lime in the mortars was 12.8. Analysıs of mortar from the granite specimen showed a content of 4.8 per cent, indicating that nearly two-thirds of the lime had been dissolved out. Further evidence of the loss of lime was found in the heary white crust which formed on the exposed bottoms of the concrete specimens during the test. Small stalactites, quite soft to the touch, were abundant. The quantity of this deposit was not visibly different in the different tests.

The calculated loss in lime of the mortar was greater than the loss computed from periodical chemical analyses of the effluent water, and this is due to the fact that much of the dissolved lime was deposited upon the bottoms of the specimens as the stalactitic growth above mentioned.

There was no evidence that suspended impurities in the water had been carried into the interior of the concrete, and it is therefore supposed that the onc-inch layer of sand by which the latter was screened from the direct flow of the water was an efficient filter for the purpose. The clogging action resulting from this source may therefore be dismissed as negligible.

It may be concluded from these tests that concrete of this density tends to protect itself automatically from the action of percolating water, so that, for the period investigated at least, the flow tends to diminish to a minimum. The action of the water seems to be confined to the cement of the mortar, learing the aggregate relatively unaffected.

It is evident that, notwithstanding the ntmost precaution in mixing concrete test specimens, wide differences in permeability may obtain in specimens mixed under the same conditions of handling and by the same workman, owing to structural differences in the resulting mass. However, the results obtained are fairly comparable.

The most sensitire test for the internal changes which the concrete has undergone during percolation is the resulting strength of the concrete.

Concretes containing different cements. - A series of tests was undertaken in which the specimens were made up in the same proportions, $1: 2.5: 6$, nsing in each specimen the same coarse aggregate, a crished granite, and the same fine aggregate, a standard quartz, but using different brands of cement. The specimens were stored in damp sand for a period of 28 days, then subjected to continuous water pressure of about 
25 pounds for a period of 11 months. Parallel specimens were stored in damp sand during this period and allowed to attain their full normal strength. The table following shows the leakage and final strength of the specimens:

TABLE 15

Percolation through Concrete Specimens

\begin{tabular}{|c|c|c|c|c|c|c|}
\hline \multirow{2}{*}{ Months of percolation } & \multicolumn{6}{|c|}{ Brands of cement and grams of water passing in 10 minutes } \\
\hline & A & $\mathrm{B}$ & $\mathrm{C}$ & $\mathrm{D}$ & $\mathrm{E}$ & F \\
\hline $1 / 2 \ldots \ldots \ldots \ldots$ & 146 & 286 & 63 & 164 & 76 & 230 \\
\hline $1 \ldots \ldots \ldots \ldots$ & $15 \check{5}$ & 125 & 22 & 179 & 16 & 82 \\
\hline $2 \ldots \ldots \ldots \ldots$ & 56 & 70 & 90 & 167 & 11 & 85 \\
\hline $3 \ldots \ldots \ldots \ldots$ & 37 & 47 & 52 & 161 & 11 & 82 \\
\hline $4 \ldots \ldots \ldots \ldots$ & 72 & 28 & 37 & 65 & 7 & 45 \\
\hline $5 \ldots \ldots \ldots \ldots$ & 71 & 12 & 31 & 15 & 17 & 39 \\
\hline $6 \ldots \ldots \ldots \ldots$ & 68 & 28 & 34 & 11 & 26 & 33 \\
\hline $7 \ldots \ldots \ldots \ldots$ & 57 & 46 & 14 & 6 & 16 & 21 \\
\hline $8 \ldots \ldots \ldots \ldots$ & 40 & 43 & 12 & 2 & 5 & 11 \\
\hline $9 \ldots \ldots \ldots \ldots \ldots$ & 불 & $\cdots$ & $\ddot{i g}$ & $\cdots$ & $\cdots$ & $\cdots$ \\
\hline $10 \ldots \ldots \cdots \cdots \cdots$ & 13 & 7 & 10 & 5 & 4 & 14 \\
\hline $11 \ldots \ldots \ldots \ldots$ & 8 & 13 & 10 & 1 & 2 & 19 \\
\hline
\end{tabular}

TABLE 16

Comparison of Strength before and after Permeability Test

\begin{tabular}{|c|c|c|c|c|c|c|}
\hline & A & B & C & D) & $\mathrm{E}$ & F \\
\hline 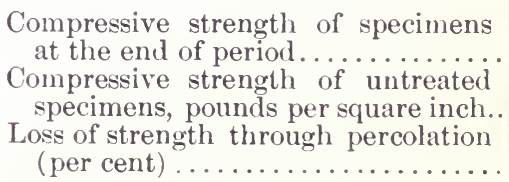 & $\begin{array}{r}770^{7} \\
1080 \\
29\end{array}$ & $\begin{array}{r}490 \\
1210 \\
60\end{array}$ & $\begin{array}{r}640 \\
1230 \\
48\end{array}$ & $\begin{array}{r}890 \\
1125 \\
21\end{array}$ & $\begin{array}{r}750 \\
1220 \\
39\end{array}$ & $\begin{array}{r}590 \\
1090 \\
46\end{array}$ \\
\hline
\end{tabular}

TOne specimen crushed. Other results are average of two specimens.

Effect of the direction of flow through concrete.-Concrete seems to offer less resistance to the flow of water when the direction of the flow is parallel to the bed than when at right angles to it. A test corering this point was made with 8 -inch cubes of concrete of the proportions $1: 4: 14$, fine and coarse aggregate being a standard crushed bluestone. 
TABLE 17

Rate of Flow in Gallons per Square Foot per Hour under 20-inch Head

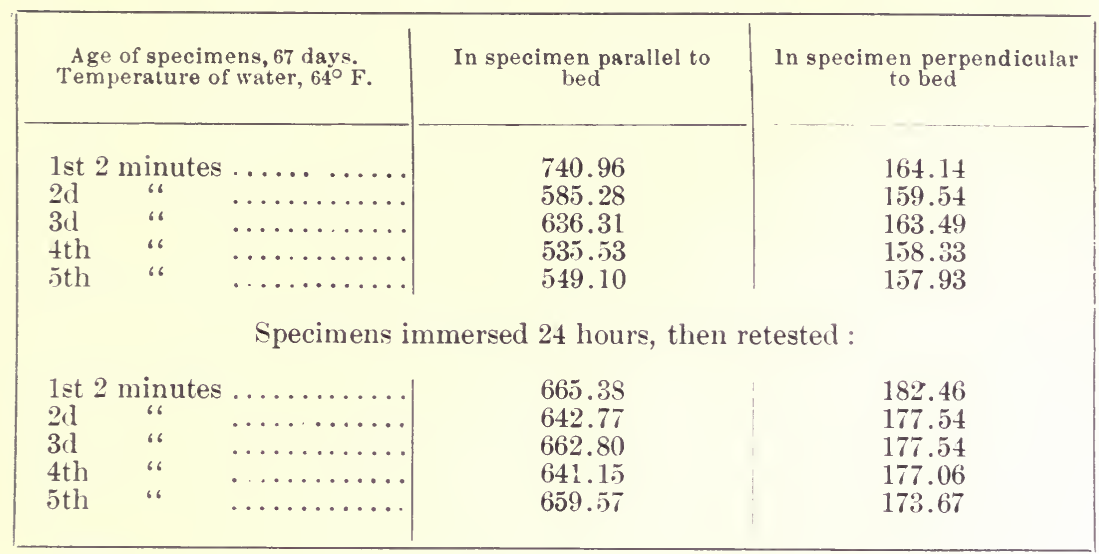

In denser concretes, this effect was not found so marked. It will be noted that after storage following the first exposure to the effect of percolating water, these specimens appear to offer less resistance to the flow of water. This may be due to the fact that in lean concretes the proporticn of capillary and subcapillary voids is smaller and that of supercapillary voids greater, and that cementing and clogging actions, which hare their greatest effect in capillary and subcapillary passages, are not so effective.

The greater flow along the bedding planes has been observed in the case of rock, and is in all respects a phenomenon of the same nature. In the case of a stratified sandstone cited by King (51), the reason is adranced that no more water can pass the more open layers, when advancing across the bedding planes, than was able to pass those of the closest texture; whereas when the flow is along the bedding planes, each particular stratum carries water in proportion to the coarseness of its texture, uninfluenced by any other.

In the case of water percolating into a concrete tumnel this would tend to emphasize lateral percolation, and in the case of disintegration would exercise, in general, a localizing influence. It is not to be assumed that this is a rigid rule, inasmuch as a large number of factors, evidently, may neutralize this influence.

From these considerations, it will be seen that the solvent effect of water upon set cement is of high importance in considering the permanence of concrete structures, and that this solvent effect tends to diminish as the set cement ages. This is not the only way, of course, that water 
may afterwards affect the metamorphism of cement. It has been pointed out by Goldbeck (43) and by White (108) that the expansion or contraction of concrete depends upon whether the concrete remains wet or dry, and that the strains caused by alternate wetting and drying of concrete may be a more fruitful cause of cracks than temperature changes.

The presence of an optimum quantity of water is necessary, however, so that the proper reactions take place in the mass of setting cement, in order that the strength may increase normally.

\section{QUALITY OF WATER AT FIRST ADDED}

Compressice strengths of neat cements gaged with various solutions.A normal Portland cement was mixed with the proper quantity of water (21 per cent by weight) in which was dissolved, in the different tests, varying concentrations of the salts indicated in the subjoined table. The cement was worked for one minute, and the plastic mass was tampert into glass cylinders approximately one inch in diameter, with the utmost precaution to avoid all air bubbles and at the same time to subject all specimens to the same pressure.

TABLE 18

Compressivestrengths of reat cement Mixed uith solutions of Tarious sults (Age of slecimens, 28 days. Arelage of two determinations)

\begin{tabular}{|c|c|c|}
\hline Mixes & $\begin{array}{l}\text { Pounds per } \\
\text { square inch }\end{array}$ & $\begin{array}{l}\text { Gain or loss, } \\
\text { per cent }\end{array}$ \\
\hline 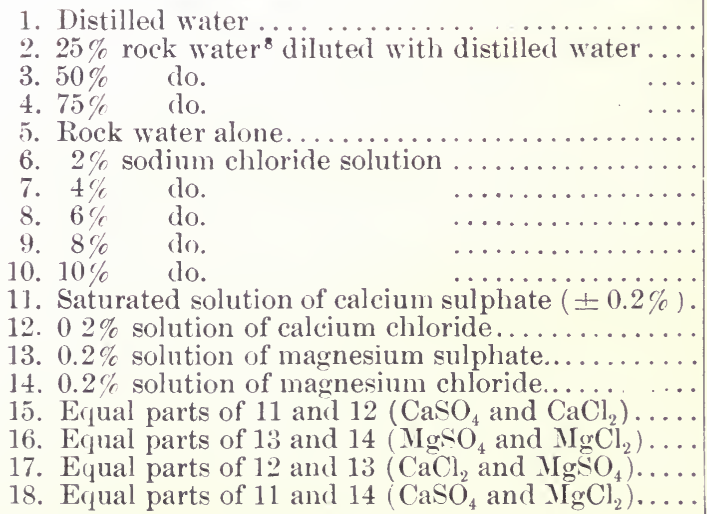 & $\begin{array}{l}7330 \\
6340 \\
6495 \\
6870 \\
5605 \\
6675 \\
5815 \\
5065 \\
4215 \\
5285 \\
7025 \\
6960 \\
6680 \\
5595 \\
6565 \\
7355 \\
5810 \\
6200\end{array}$ & $\begin{array}{l}-14 \\
-11 \\
-6 \\
-23 \\
-9 \\
-21 \\
-31 \\
-43 \\
-29 \\
-4 \\
-5 \\
-9 \\
-23 \\
-10 \\
+0.6 \\
-21 \\
-15\end{array}$ \\
\hline
\end{tabular}

${ }^{8}$ This water contained: CaO, 1177 parts per million.

$\mathrm{MgO}, 226$

$\mathrm{SO}_{3}, 408$

Cl, 43690 
The glass cylinders containing the cement were then stored in a damp closet for 28 days, when the cylinders were broken out, and two specimens, each exactly one diameter high, cut from each cylinder. These were put into water for a few hours, so that they might be in the moist state when crushed. The cylinders were kept in the damp closet instead of being stored under water, to avoid leaching out the salts contained in the mixing water, thus obtaining the maximum effect of the dissolved salts.

It will be noted that there is a decided loss of strength in all but one case (number 16). This particular case may be explained by the probable formation of an oxychloride, by the magnesium chloride and the magnesium hydroxide liberated by the action of the magnesium sulphate upon the calcium hydroxide of the cement. The oxychloride formed from these two materials has a tensile strength far superior to that of Portland cement itself, and its presence probably counteracted the destructive action of the salts upon the cement. It is probable, however, that, at longer periods, this increase would disappear and become a decrease. Otherwise, the presence of saline matter dissolved in the mixing water seems to have a decided deleterious effect upon the strength of cement. This point is of marked importance in construction, inasmuch as the problem of mixing water is often solved by using the water nearest at hand, without inquiry into its qualities.

It is the custom to specify that the water used in mixing concrete shall be free from oil, acid, strong alkalies or vegetable matter $(\mathbf{7} \%)$; but such a specification does not corer the case in point, and the presence of large quantities of dissolved salts in water used for construction is easily orerlooked. In concrete construction, it is of the utmost importance that the water which may be used in mixing be additionally subjected to such tests as will reveal either its mineral content or its action when mixed with cement and possible subsequent attack thereon.

The action of sodium chloride appears to be nearly directly proportional to the amount employed. This salt is used in mixing water for construction carried on in cold weather, in order to prevent freezing of the deposited concrete. Its effect upon the strength of cement, if used in excessive quantities, is, as has been shown above, likely to become a serious matter. Under the conditions of construction which generally prerail, however, much of the salt may be leached out of the mass. The results above represent a condition of maximum attack.

Dieckmann (25) recommends the use of from 1 to 2.5 per cent of salt for concrete to be laid in cold weather, but states that percentages larger than this cause a marker decrease in the strength. 
Effect of gaging with various solutions upon the strength of mortars afterward stored in water.-The above tests do not show, of course, a normal condition, since no water came into contact with the cement after it had set. Working with more porous material, a 1:3 mortar, so that in storage a heightened subsequent water action might take place, the following results were obtained:

TABLE 19

Effect of various Salts dissolved in the Mixing Water, upon the strength of 1:3 Mortar

( Silnd, screened Cow Bay. Specimens stored in damp closet for $2+$ hours, then continuously in water for the rest of period)

\begin{tabular}{|c|c|c|c|c|}
\hline \multirow{2}{*}{ Mixes } & \multicolumn{3}{|c|}{$\begin{array}{l}\text { Compressive strength, } \\
\text { pounds per square inch }\end{array}$} & \multirow{2}{*}{$\begin{array}{l}\text { Number of } \\
\text { specimenss }\end{array}$} \\
\hline & 7 days & 28 days & 3 months & \\
\hline 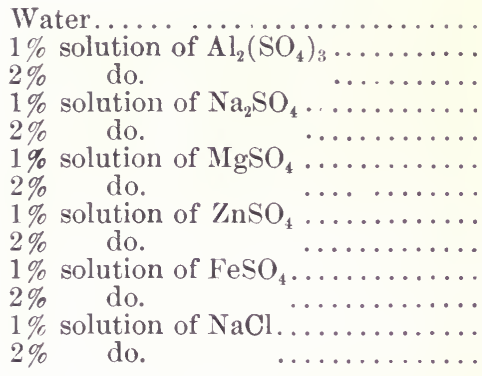 & $\begin{array}{r}815 \\
1005 \\
945 \\
1010 \\
885 \\
910 \\
865 \\
935 \\
1090 \\
930 \\
840 \\
1105 \\
1000\end{array}$ & $\begin{array}{l}1475 \\
1185 \\
1310 \\
1520 \\
1240 \\
1625 \\
1410 \\
1595 \\
1580 \\
1605 \\
1480 \\
1385 \\
1035\end{array}$ & $\begin{array}{l}2600 \\
1805 \\
2170 \\
2420 \\
2100 \\
2145 \\
2115 \\
2710 \\
2500 \\
2670 \\
2710 \\
2000 \\
1685\end{array}$ & $\begin{array}{l}1,3,3 \\
3,2,1 \\
3,3,3 \\
3,3,3 \\
1,3,3 \\
2,3,3 \\
2,3,3 \\
3,3,2 \\
3,1,2 \\
3,3,3 \\
2,1,1 \\
3,3,3 \\
2,3,3\end{array}$ \\
\hline \multirow{2}{*}{$2 \%$ do. $\quad \ldots \ldots \ldots \ldots \ldots$} & \multicolumn{3}{|c|}{$\begin{array}{l}\text { Tensile strength, pounds per } \\
\text { square inch }\end{array}$} & \\
\hline & 7 days & 28 days & 3 months & \\
\hline 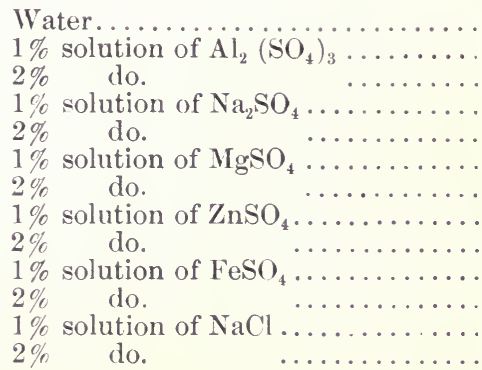 & $\begin{array}{l}179 \\
208 \\
193 \\
216 \\
205 \\
194 \\
185 \\
126 \\
205 \\
201 \\
184 \\
211 \\
224\end{array}$ & $\begin{array}{l}272 \\
272 \\
262 \\
290 \\
300 \\
260 \\
246 \\
263 \\
272 \\
266 \\
258 \\
261 \\
279\end{array}$ & $\begin{array}{l}326 \\
321 \\
340 \\
354 \\
343 \\
317 \\
283 \\
315 \\
319 \\
314 \\
311 \\
310 \\
310\end{array}$ & $\begin{array}{l}5,6,6 \\
6,6,6 \\
4,6,5 \\
6,6,6 \\
4,6,6 \\
3,6,6 \\
4,6,6 \\
2,5,6 \\
3,6,6 \\
5,6,6 \\
5,6,6 \\
6,6,6 \\
5,6,5\end{array}$ \\
\hline
\end{tabular}


The general conclusion that may be drawn from these values is that the effect of electrolytes in the mixing water, when the cement is afterwards subject to immersion in water, is to increase the strength at the early periods ( 7 and 28 days), but later to depress it (15). In general, the more concentrated solutions give a greater depression of strength. The early increase in strength is probably due, in the presence of an optimum quantity of water, to additional cementing or void-filling material precipitated in the pores of the mortar by reaction between the added electrolytes and the solutions resulting from the action of water upon cement. This deposited material may, in its later history, revert to a soluble form and be washed away, leaving abnormal voids, or else in its growth may disrupt the cells it occupies, in either case reducing the strength.

Effect of gaging grout with rock waters.-In grouting deep tunnels, the question has arisen as to the advisability of using the rock water at hand when fresh water was inaccessible. The water available in the instance in hand was an effluent from a shale bearing a small proportion of pyrites, and when it issued from the rock face it contained a quantity of dissolved hydrogen sulphide. As none of the water was immediately arailable for a laboratory test, an artificial mixture was made up, in which the quantities of dissolved salts and hydrogen sulphide occurring in the natural water was purposely exaggerated, to obtain accelerated effects.

TABLE 20

Analysis of the Artificinlly Mineralized Water

\begin{tabular}{|c|c|c|}
\hline $\mathrm{H}_{2} \mathrm{~S}$ & $\ldots \ldots \ldots \ldots \ldots \ldots \ldots \ldots \ldots \ldots$ & $\begin{array}{l}\text { per million } \\
891\end{array}$ \\
\hline $\mathrm{CaO}$ & $\ldots \ldots \ldots \ldots \ldots \ldots \ldots \ldots \ldots \ldots$ & 1764 \\
\hline $\mathrm{MgO}$ & 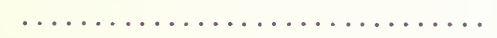 & $1+61$ \\
\hline $\mathrm{SO}_{3}$ & $\ldots \ldots \ldots \ldots \ldots$ & 1948 \\
\hline & . & 2920 \\
\hline
\end{tabular}

A grout was made up according to specifications, using a normal Portland cement, and Cow Bay sand with 100 per cent passing 10 sieve, 75 per cent passing 40 sieve; in the proportions $1: 11 / 2$ with 35 per cent of liquid. The wet mix was poured into glass cylinders, kept 24 hours in air until set had dereloped and immersed in water.

Four sets of three specimens each were made, the first set mixed with 3.5 per cent of distilled water; the second, 35 per cent of the water above mentioned; the third, 35 per cent of a 10 per cent dilution of this water, and the fourth, 35 per cent of a 1 per cent dilution.

To discrepancy was observed in the setting time, as all the specimens 
dereloped a fair set within 24 hours. The grouts mixed with the undiluted sulphide water turned a dark green, but otherwise no change was noticed in these or any other specimens. Three cylinders one diameter high were cut from each set of specimens, and, after storing 28 days in distilled water, were crushed.

TABLE 21

Compressive Strength of Grout Mixed with Different Proportions of Water Containing Hydrogen sulphide

(Average of three specimens, age 28 days)

Pounds per

Mixes

square inch

Distilled water ........................... 1424

Cndiluted sulphide water....................... 160s

10 per cent of sulphide water, 99 per cent of distilled water... . 20ss

1 per cent of sulphide water, 99 per cent of distilled water..... 1110

Apparently, considering the arerage of the last three values, water of this composition will have no evil effect at 28 days upon the grout with which it is gaged.

Three series of tests were undertaken, in which a $1: 3$ mortar of Ottawa sand and a cement of good quality was mixed with Croton water, and with two typical rock waters encountered in tunnel work.

TABIE 22

Allalyses of Rock Watros

\begin{tabular}{|c|c|c|}
\hline & Parts & million \\
\hline & $\mathrm{E}$ & $W$ \\
\hline $\mathrm{C} a \mathrm{O} \ldots$ & 85 & 943 \\
\hline $\mathrm{MgO}$. & 159 & 156 \\
\hline$\ldots \ldots \ldots \ldots \ldots \ldots \ldots \ldots \ldots \ldots \ldots$ & 73 & 172 \\
\hline $\mathrm{Cl}$. & 1380 & 3420 \\
\hline Total solids & 2978 & 7929 \\
\hline
\end{tabular}

The normal amount of water was used to mix the mortars in each case, and the briquettes were stored in the damp closet orer the stated periods.

TABLE 23

Tensile strength of $1: 3$ Mortar: Mixed with Tarions Saline Waters

\begin{tabular}{|c|c|c|c|c|}
\hline \multirow{2}{*}{ Mixed with- } & \multicolumn{3}{|c|}{ Pounds per square inch } & \multirow{2}{*}{$\begin{array}{l}\text { Number of } \\
\text { specimens in } \\
\text { average }\end{array}$} \\
\hline & 7 days & 28 days & 3 months & \\
\hline 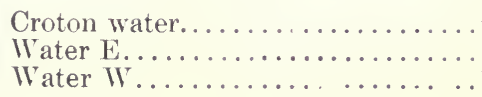 & $\begin{array}{l}302 \\
297 \\
296\end{array}$ & $\begin{array}{l}322 \\
343 \\
335\end{array}$ & $\begin{array}{l}344 \\
363 \\
383\end{array}$ & $\begin{array}{l}6,5,6 \\
6,6,6 \\
6,6,6\end{array}$ \\
\hline
\end{tabular}


As was found in the case of the grouts last mentioned, waters of this, general concentration do not appear to affect the strength of cement mortars with which they are gaged, and the probabilities are that no serious effects will result from this cause alone.

\section{QLALITY OF WATER THAT MAY SUBSEQUENTLY COME INTO CONTACT} WITH THE SYSTEM

Theoretical considerations.-The action of dissolved salts in water tliat comes into contact with concrete, where such action is deleterious to the concrete, has been carefully studied by a large number of investigators $(68,81,96,112)$. Of the salts which have been found injurious, magnesium sulphate and magnesium chloride seem to have the greatest effects. What concentration of dissolved salts is necessary in order that disintegrating effects shall manifest themselves cannot be definitely stated. This is a field problem and is subject to wide variations under different conditions.

A water containing relatively little dissolved material, acting under farorable conditions of porosity, pressure and wide temperature changes inon one concrete, may accomplish failure of the structure; while another water, of high saline content, meeting a dense, impervious concrete, not forced through the mass by pressure and under conditions of small temperature change, may have practically no action. Manifestly, unless these varying conditions are taken into account, it is unscientific to draw any conclusions regarding the attack of different waters or the resistivity of different cements.

It may be laid down as a basic principle, however, that the denser a concrete, other conditions being equal, the greater its resistance to the attack of saline waters $(10,41,5 \%)$. The alkali waters of the Western states hare given a great deal of trouble in concrete construction. Most experimenters conclude that their action upon concrete is in the main mechanical and due to the disruptive force of crystallizing or efflorescing salts deposited in the pores by intermittent submergence and drying out $(30,38,49,56)$.

Of course, as has been pointed out, action of this sort is not confined to concrete, and any material of construction possessing porosity is liable to a similar disintegration. The remedy, therefore, is to prevent the penetration of the saline solutions by the employment of courses of permanent, impenetrable materials, preferably asphaltic layers.

Where the attack is not mechanical but chemical, this remedy is also applicable. Unfortunately, there are examples of construction which are exceptions, and, in these, some change in the chemical or mechanical 
constitution of the cement is the only way to prevent decomposition. In concrete block construction, where the blocks may be made long before they are actually put into the structure, it is found of great advantage to allow them to harden in air or in damp sand, and so permit to a great extent the carbonation of the lime compounds. Some investigators claim excellent results from this method $(41,55)$.

As to the modifications in the constitution of the cement that will combat the action of saline solutions, there is a great disparity of opinion, which possibly is based upon lack of standardization of experimental conditions. It is generally conceded that high silica cements are best stiited for the purpose ( $\%$ ). The use of puzzolan cements, or of additions of puzzolan to the cement in use, is also well recommended $(\boldsymbol{F}, 3 \%$, $66)$; and the addition of clay, burnt or dehydrated, finds favor with some $(7,75)$. As to the lime content of the cement, opinions are divided whether it should be high $(5,41)$ or low' $(92)$.

Cement of greater density $(5 \%)$ and cement ground to a greater fineness than usual ( 72 ) are farorably commented upon. The subject, because of its great complexity and because of the questionable value of laboratory results, is at present in a chaotic state. The length of time that must elapse before judgment may be passed upon the permanence of a material under these conditions and the corresponding newness of the field of Portland cement render present conclusions largely a matter of speculation.

Effect of storage in various saline solutions upon the strength of mortar.-In order to study the relative resistance to saline solutions offered by cements rarying in chemical composition and in fineness of grinding, a series of 132 2-inch mortar cubes was made up, in the proportion of $1: 3$, with standard Ottawa sand, the cements used being

A. A high silica cement

B. A low silica cement

C. A cement of ordinary composition, sifted and remixed so that 98.8 per cent passed the 100 mesh sieve and 88.6 per cent passed the 200 mesh sieve

D. The same cement as C sifted so that 92 per cent passed the 100 sieve and 75 per cent passed the 200 sieve 
TABLE 24

Analyses of the Cements Used in Tests with Saline Solutions

\begin{tabular}{|c|c|c|c|}
\hline & \multicolumn{3}{|c|}{ Per cent } \\
\hline & $\mathbf{A}$ & в & c \\
\hline $\mathrm{SiO}_{2} \ldots$ & 23.50 & 19.74 & 22.99 \\
\hline $\mathrm{Fe}_{2} \mathrm{O}_{3} \ldots$ & 2.36 & 2.75 & 2.42 \\
\hline $\mathrm{Al}_{2} \mathrm{O}_{3} \ldots \ldots \ldots \ldots \ldots$ & 7.28 & 8.77 & 6.79 \\
\hline ( & $\begin{array}{ll}62 & 18\end{array}$ & 60.86 & 60.84 \\
\hline $\mathrm{MgO} .$. & 2.29 & 2.86 & 4.14 \\
\hline $\mathrm{SO}_{3} \ldots \ldots \ldots \ldots \ldots \ldots$ & 1.11 & 1.39 & 1.76 \\
\hline $\mathrm{CO}_{2} \mathrm{H}_{2} \mathrm{O}$, alkalies...... & 1.28 & 3.63 & 1.06 \\
\hline
\end{tabular}

The cubes were stored $2 t$ hours in the damp closet, and then transferred to the solutions mentioned in the following table, three cubes to each liquid, and there stored for three months, then broken.

TABLE 25

Compressive strength of Uortars stored for Three Months in Tarious Saline solutions

(Each value is the average of three determinations)

\begin{tabular}{|c|c|c|c|c|c|c|c|c|}
\hline \multirow{2}{*}{ Storage medium } & \multicolumn{8}{|c|}{ Pounds per square inch } \\
\hline & $\begin{array}{l}\text { High } \\
\text { silica }\end{array}$ & $\begin{array}{r}\text { Gain, } \\
\text { per } \\
\text { cent }\end{array}$ & $\begin{array}{l}\text { Low } \\
\text { silica }\end{array}$ & $\begin{array}{c}\text { Gain, } \\
\text { per } \\
\text { cent }\end{array}$ & $\begin{array}{l}\text { Finely } \\
\text { ground }\end{array}$ & $\begin{array}{c}\text { Gain, } \\
\text { per } \\
\text { cent }\end{array}$ & $\begin{array}{l}\text { Coarsely } \\
\text { ground }\end{array}$ & $\begin{array}{l}\text { Gain, } \\
\text { per } \\
\text { cent }\end{array}$ \\
\hline Croton water... & 2217 & & 2462 & & 2134 & $\ldots \ldots$ & 2066 & \\
\hline $\begin{array}{l}\text { Sodium } \\
\text { sulphate, } 10 \%\end{array}$ & $\begin{array}{l}2267 \\
3264\end{array}$ & $\begin{array}{r}2 \\
47\end{array}$ & $\begin{array}{l}2090 \\
2035\end{array}$ & $\begin{array}{l}-15 \\
-18\end{array}$ & $\begin{array}{l}3266 \\
2223\end{array}$ & $\begin{array}{r}53 \\
4\end{array}$ & $\begin{array}{l}2273 \\
2262\end{array}$ & $\begin{array}{r}10 \\
9\end{array}$ \\
\hline $\begin{array}{l}\text { Magnesium } 5 \% \\
\text { sulphate, } 10 \%\end{array}$ & $\begin{array}{l}3244 \\
2604\end{array}$ & $\begin{array}{l}46 \\
18\end{array}$ & $\begin{array}{l}1787 \\
2646\end{array}$ & $\begin{array}{r}-28 \\
7\end{array}$ & $\begin{array}{l}2233 \\
3003\end{array}$ & $\begin{array}{r}5 \\
42\end{array}$ & $\begin{array}{l}2759 \\
2489\end{array}$ & $\begin{array}{l}33 \\
20\end{array}$ \\
\hline $\begin{array}{l}\text { Sodium } \\
\text { chloride, } 10 \%\end{array}$ & $\begin{array}{l}2365 \\
1778\end{array}$ & $\begin{array}{r}7 \\
-20\end{array}$ & $\begin{array}{l}1785 \\
2019\end{array}$ & $\begin{array}{l}-28 \\
-18\end{array}$ & $\begin{array}{l}2305 \\
2968\end{array}$ & $\begin{array}{r}8 \\
40\end{array}$ & $\begin{array}{l}2695 \\
2044\end{array}$ & $\begin{array}{r}30 \\
-1\end{array}$ \\
\hline $\begin{array}{l}\text { Magnesium } 5 \% \\
\text { chloride, } 10 \%\end{array}$ & $\begin{array}{l}2331 \\
1757\end{array}$ & $\begin{array}{r}5 \\
-21\end{array}$ & $\begin{array}{l}1827 \\
1769\end{array}$ & $\begin{array}{l}-26 \\
-28\end{array}$ & $\begin{array}{l}2731 \\
2570\end{array}$ & $\begin{array}{l}33 \\
20\end{array}$ & $\begin{array}{l}2305 \\
2269\end{array}$ & $\begin{array}{l}12 \\
10\end{array}$ \\
\hline 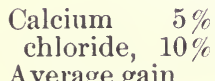 & $\begin{array}{l}2653 \\
2224\end{array}$ & $\begin{array}{r}19 \\
0\end{array}$ & $\begin{array}{l}2516^{9} \\
1994\end{array}$ & $\begin{array}{r}2 \\
-19 \\
\end{array}$ & $\begin{array}{l}2219 \\
2042\end{array}$ & $\begin{array}{r}4 \\
-4\end{array}$ & $\begin{array}{l}1808 \\
2238\end{array}$ & $\begin{array}{r}-13 \\
8\end{array}$ \\
\hline (per cent)... & & 10 & $\ldots$ & -17 & $\ldots$ & 20 & $\ldots$ & 12 \\
\hline
\end{tabular}

${ }^{9}$ Average of two determinations. 
The general deductions from these experiments for the period covered are that the high silica cement, notwithstanding its slower rate of hardening, resists the action of these dissolved salts better than the low silica cement, and the finely ground cement better than the coarsely ground. Moreover, with the concentrations used, the stronger solutions in nearly every case had a more destructive effect upon the strength of the mortar than the weaker.

The strengths here obtained by storage in salt solutions are in general decidedly greater than those obtained by storage in fresh water. Examination of the cubes, when removed from the solutions at the end of the test period, revealed under a lens that the exterior was being attacked, minute pittings being quite distinct.

The strength attained by these specimens may be considered as a resultant of the balancing of two effects: the deposition of crystallized or precipitated material in the roids, which by packing the spaces with solids will increase the compressive strength; the creation of additional roids by direct solution or by the disruptive effect of metathetically prodnced material. It is probable that the disintegrating effect for these concentrations is reached considerably beyond three months' exposure. From the increases in the compressive strength, it is likely that at this period a great deal of crystallization or precipitation has proceeded, orerbalancing in the main the disruptive effects. This is a general Acduction, and single instances are notable in which the reverse holds good.

In the case of the finely ground cement, the density of the mortar made therefrom has prevented the disruptive effect to a greater degree; and thus the deposition, while not necessarily as much as in the coarser cement mortars, has had a more marked effect in increasing the strength.

Effect of storage in rock water upon the strength of lean cement mortars.-A series of briquettes of 1:4 Ottawa sand mortars was made up, using a normal Portland cement of high quality. The mix was made lean purposely to accelerate whaterer disintegrating effect might occur. Batches of the briquettes were stored in bottles in the laboratory for the i-day and 28-day tests, and additional series were stored in the field, for the longer tests, at stations where the waters in question were encountered. The field series were stored in running water, and the action upon these should be more severe than upon the laboratory specimens stored in still water. In each case a parallel test was made by storing a series in pure drinking water. 
TABle 26

Tensile Strength of 1:4 Mortars, stored in Rock Water

\begin{tabular}{|c|c|c|c|c|c|c|c|c|c|}
\hline \multirow{3}{*}{ Water } & \multicolumn{8}{|c|}{ Strength, pounds per square inch } & \multirow{3}{*}{$\begin{array}{l}\text { Specimens } \\
\text { in average }\end{array}$} \\
\hline & \multicolumn{4}{|c|}{ Stored in laboratory } & \multicolumn{4}{|c|}{ Stored in field } & \\
\hline & 7 days & Gain & 28 days & Gain & 3 mos. & Gain & 6 mos. & Gain & \\
\hline $\begin{array}{l}\text { Drinking.. } \\
\text { "A }, \ldots . . \\
\text { " } \mathrm{B}, ", \ldots\end{array}$ & $\begin{array}{l}211 \\
220 \\
203 \\
221\end{array}$ & $\begin{array}{l}+4 \% \\
-4 \% \\
+4 \%\end{array}$ & $\begin{array}{l}297 \\
312 \\
287 \\
288\end{array}$ & $\begin{array}{r}5 \% \\
-3 \% \\
-3 \%\end{array}$ & $\begin{array}{l}320 \\
323 \\
313 \\
340\end{array}$ & $\begin{array}{r}1 \% \\
-2 \% \\
6 \%\end{array}$ & $\begin{array}{l}324 \\
247 \\
303 \\
328\end{array}$ & $\begin{array}{r}-24 \% \\
-5 \% \\
1 \%\end{array}$ & $\begin{array}{l}12,12,6,6 \\
12,12,6,6 \\
12,12,6,6 \\
12,12,6,6\end{array}$ \\
\hline
\end{tabular}

TABLE $2 \overline{6}$

Analyses of Rock Waters in Previous Experiments

\begin{tabular}{|c|c|c|c|}
\hline & \multicolumn{3}{|c|}{ Parts per million } \\
\hline & A & B & C \\
\hline 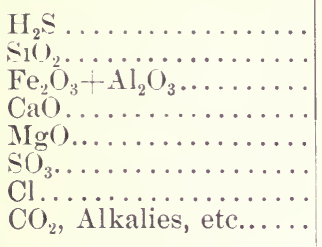 & $\begin{array}{r}44 \\
20 \\
7 \\
284 \\
124 \\
727 \\
826 \\
949\end{array}$ & $\begin{array}{r}15 \\
5 \\
399 \\
118 \\
353 \\
546 \\
459\end{array}$ & $\begin{array}{r}4 \\
4 \\
87 \\
38 \\
31 \\
270 \\
317\end{array}$ \\
\hline Total solids....... & 3037 & 1895 & 751 \\
\hline
\end{tabular}

The drinking water used to store the blanks contained in neither case more than 100 parts per million of total solids.

The most consistent reduction of strength, although a slight one, is observed in the case of water B, a fairly typical sulphato-chloride water according to Clarke's classification (18, p. 190). A strikingly high and sudden reduction occurs at six months in water $A$, a sulphate water charged with hydrogen sulphide, while water C, a chloride water, shows no marked reduction of the strength, which, however, may be due to a low salinity.

The six-month briquettes stored in water A showed superficially much minute pitting, due to the removal of the sand grains, presumably by solution of the matrix of the cement. Two sections were cut from one of these briquettes, one transverse and one longitudinal, in the hope of discovering whether any replacement of the original material by sul- 
phates or sulphides was going on. The microscopic examination did not reveal anything of the sort, the sections being in all respects similar to sections cut from the briquettes stored in drinking water. It was concluded therefore that the loss of strength was due to actual removal of material by solution rather than by replacement with material which would cause disintegration through a discrepancy in volume.

The legitimate general deduction from these tests is that, orer the period of experiment, the effect of these waters is greater in roid filling by crystallization or precipitation than in disintegration by solution or disruption.

The void-filling material, if of a stable nature and not likely to return into solution, should be in a measure a protection against the further entrance of the saline solutions. It has been mentioned that this property has been suggested of magnesium liydroxide (70). Probably upon this possibility is based the reported effect of chemically inert fine materials, added to the cement for protection against such destructive action.

\section{Summar of Experimental Results}

1. Increase of temperature of the water with which cement is mixed causes acceleration of the set up to a certain maximum temperature, then a retardation.

2. Storage in cold water, without freezing, retards the hardening of neat cement, and that of mortars more.

3. Increase in the proportion of fine particles in a cement decreases the permeability of mortar made therefrom.

4. Mechanical agitation increases the strength of cement up to a certain maximum time; after which, if continued, it resluces it.

5 . The setting of cement is accelerated by dryness of the atmosphere.

6. An excess of mixing water progressively reduces the strength of cement. This effect is partly reversive of itself, and the reversion may be increased by additional colloidal material in the original cement.

\%. Water percolating through concrete dissolves the lime of the cement chiefly, and this effect tends to neutralize itself by "healing."

8. Percolation through concrete preferably follows the bedding planes.

9. Salts in solution in the mixing water tend to lower the strength of cement. This effect may be neutralized by precipitation in the pores.

10. Storage in saline water affects low silica cements more than it does high silica, and coarsely ground cements more than it does finely ground cements. 


\section{General Conclusions}

In general, the metamorphism of Portland cement represents on an accelerated scale the processes which occur in natural rocks. The acceleration is of course due to the ease with which water has access to the finely comminuted particles in the initial stages of metamorphism. Many of the minerals found in natural rocks, when ground as finely as, or finer tlıan Portland cement, undergo vastly accelerated reactions in the presence of water; colloidal bodies are thereby produced, and the water is rendered alkaline (18).

The end product of prolonged water action on Portland cement bears a striking qualitative similarity to the end product in the kaolinization of feldspars. The same transformations evidently occur in both cases,the alkalies and the lime are abstracted, and the water and alumina contents increased. The exceeding fineness and high adsorptive power of the resulting products are also similar. The action of water on nearly all silicate minerals is, in effect, a repetition of this process.

The peculiar adsorptive properties of colloidal bodies render these liable to coagulation. As has been pointed out in preceding pages, much of the cementing material of conglomerates and sandstones, except where calcitic, may have its origin in a similar phenomenon.

On a natural scale, the action of water is greatly retarded, because of the larger size of the bodies acted upon, and the consequent paucity of surface upon which water may exert its influence. When Portland cement has properly undergone its initial metamorphism, the setting process being complete and the hardening process in great part so, it approaches the condition of a natural metamorphic rock, and activities towards its further change are katamorphic and vastly slower in their results than the initial changes. The component particles have now become consolidated and the surface offered to the action of water is minimized. Of course, this is truer of neat cement than mortar and truer of mortar than of concrete, these being in the order of increasing porosity.

The hypothesis that crystal formation is responsible for the strength of hardened cement is not so complete and satisfactory as the colloidal hypothesis just referred to. In a compact mass, the growth of crystals can hardly be considered anything but an element of weakness. As has been shown by the foregoing results, the effects of varying some of the conditions of the action of water upon cement are best explained by considering the hardening a coagulative process rather than a process of crystallization. 


\section{BibLIOGRAPHY}

1. Abstract: Influence of the Proportion of Water on the Compressive Strength of Cement Mortar and Coucrete. Conc. Eng.. 3, 316. 1908.

2. Ambrons, H.: Crystallization and Gel Formation in the Hardening of Cement. Tonind. Zig., 33, 270. 1909.

3. Axderson, A. O.: The Incrustation and Absorption of Concrete. Proc. Am. Soc. Test: Materials, July, 1911; reported in Cement Age, 13. 1911.

4. Anderson, G. G. : The Effect of Alkali on Concrete. 'Trams. Am. Soc. C. E., 67, 572.1910.

5. Arox.: Tests on Concrete in Sea Mater. Eng. Yews, 64, 483. 1910.

6. Ashuer, H. E.: The Colloid Matter of Clay and its Measurement. Bull. 388, U. S. G. S. 1909.

7. Bied ANd Viviens: Decomposition of Mortar's. (Report.) I'roc. Internat. Soc. Test. Materials. 1909.

S. Binckley, G. S. : Experiments on the Coarser Particles in Cements. Eng. Record, 61, 212. 1909.

9. Blount, B.: The Setting of I'ortland Cement. Eng. Digest, 3, 135. 1908.

10. Brown, F. W. Action of Alkali Water on Cement. Cement, 9, 9:3.

11. Burchartz, H.: Researches upon Mortar and Concrete Frozen and again Thawed Out. Mt. Kgl. Materialpruf, 28, 276. 1910.

12. —_ Properties of German Portland Cements. Cement Age, 10, 250. 1908 .

13. Burke ANd P'inckner: The Action of Alkali Salts upon Portland Cement. J. Ind. and Eng. Chem, 3, 317. 1911.

14. Cameron, F. K.: Application of the Theory of Solid Solutions to the study of Soils. Report No. 64, Div. of Soils, Dept. of Agriculture.

15. Carpenter, R. C.: Materials which Retard the Activity of Portland Cement. Cement, 8, 21.

16. Chapmax, C. M.: Waterproofing with Water. Eng. Record, 62, 767. 1910.

17. Clarke, E. C.: 'Trams. Am. Soc. C. E., 14, 158. 1885.

18. Clarke, F. W.: The Data of Geochemistry. (Second Edition.) Bull. 491 , U. S. G. S. 1911.

19. Cochran, J.: Directions and Suggestions for the Inspection of Concrete Materials. Engineering and Contracting, 37, 115. 1912.

20. Committee of Assn. IR. I. Superintendents: T'le Action of Sea Water on Concrete. (Report.) Conc. Eng., 2, 139. 1907.

21. Cushmax, A. s.: The Effect of Watel on Rock Powders. U. S. Dept. of Agriculture. Burean of Chemistry, Bulletin 92. 1905.

22. D'Axs, J.: Do Clay and Cement Adsorb $\mathrm{CO}_{3}$ Ions? Z. Chem. Ind. Kolloide, 6, 38. 1910.

23. Decker, G.: The Indening of Hydraulic Cements. Tonind. Ztg., 33, 1493.1909.

24. Desch, C. H.: The Chemistry and 'Testing of Cement. London, 1911.

2.). Difckmann, G. P.: The of Concrete in Freezing Weather. Rock Produets, 9, 52. 1909.

26. Ditter and Jesser: 'Thermochemical Experiments upon Sintered Portland Cement Mixtures. Zentrall,. Hydr. Zement, 1, 71. 1910.

27. Doelter, C.: Fusions of Calcium Metasilicate and Calcium Aluminmm Silicate. Zentralbl. IIydr. Zement, 1, 104. 1910. 
28. Doxath, E. : Behavior of Certain Liquids towards Cement and Concrete. Chem. Ind., 34, 123. 1910.

29. Durs. W.: Effect of Sewage Gases on Concrete Work. Cem. Eng. News, 22, 434. 1910.

30. Editorial : Effect of Salt Solutions on the set and Durability of Concrete. Conc. Eng., 3, 318. 1908.

31. : Effect of Temperature on the set of Concrete. Cement Record, 1,24 .

32. - What Percentage of Clay is it Safe to Permit in Sand for Cement Mortar? Eng. News, 57, 620. 1907.

33. - - The Effect of Clay in Cement Mortar. Ens. Record, 55, 703. 1907.

34. - The Micrography and Constitution of Cement. Tonind. Ztg., 32, 1681. 1908.

35. - R : Retempered Mortar as a Bonding Material. Cement Age, 13, 97. 1911.

36. FALK, M. S. : Cements, Mortar's and concretes. New York, 1904.

37. Feret, M. R.: Resistance of Cements to Sea Watel Increised by Admixtures of Puzzuolan. Cem. Eng. News, 22, 11. 1910.

35. Fısk, A. J.: Effect of Alkali on Cement Mortars. Eng. News. 64, 168. 1910.

39. Fuller. W. P.: The Law's of I'roportioning Concrete. Report to the Aqueduct Commissioners. New York. 1905.

40. Gadd, W. I. : Composition of a Number of Proprietary Mixtures for Waterproofing Concrete. Conc. and Const. Eng. 3, 5t. 1908.

41. Gary axd Schxemer: Behavior of Ilydraulic Cement in Sea Water. IIt. Kgl. Materialpruf., 27, 2:39. 1909.

42. Gillmore, Gen. Q. A.: Cements, Limes and Plasters.

43. Goldbeck, A. T.: Expansion and Contraction of Concrete While Hardening. Proc. Am. Soc. Test. Mat., 11, 563. 1911.

44. Greendan, R. S.: Practical Tests of sind and Glavel Ploposed for Cse in Concrete. Proc. Am. Soc. Test. Mat., 1, 575. 1911.

45. Gromsley, C. I.: The Gypsum of Michigan. Geol. Surr. Mich., 9, (2). 138. 1904 .

46. Headiex, IV. I'.: The Destruction of Concrete by Alkali. Expt. Sta. Color. State Ag. Coll., Bull. 132.

47. Heiser, A.: The Grinding Process and the Setting of Portland Cement. Tonind. Ztg., 34, 936. 1910.

48. JAxda, F.: Theories of the Setting and Inardening of Portland and Rom:un Cements. Desterr. 7. Berg. IIïttenw., 56, 432. 1908.

49. Jewett, J. Y.: Cement and Concrete Work of the T. S. Reclamation Service, with Notes on the Action of Alkali Waters. Proc. Am. Soc. Test. Materials, 8, 480 . 1908.

50. Karl: Effect of Sewage on Concrete. Eng. Record, (;2, 28. 1910.

51. Kixg, F. H.: Principles and Conditions of the Novement of Ground Waters. 19th Annual Rep., I. S. G. S., part 2. 1899.

52. Le Chatelier, H.: Recherches sur les Mortiers Hydrauliques. Paris. 1904 .

53. — : The Decomposition of Cements. Proc. Tth Int. Cong. Applien Chem.. London, Sec. 2, 10, 5. 1909. 
54. Mackenzie, W. B.: The Disintegration of Concrete Exposed to Sea Water between High and Low 'Tides. Eng. News, 58, 472. 1907.

55. Matthews, E. R.: Action of Sea and Fresh Water on Cement and Concrete. Eng. Digest, 5, 5ำ. 1909.

56. Matthews and Watson: Effect of Freezing and Immersion upon Cement and Cement Mortar. Eng. Digest, 4, 405. 1908.

57. Marnard, E.: Iron Ore Cement. Cem. Eng. News, 22, 243, 1910.

58. _ : Solution and Decomposition of Cements. Tonind. Ztg., 33, 1462. 1909.

59. McGee, IT J : Outlines of IIydrology. Bull. Geol. Soc. Amer., 19, 192. 1907.

60. McKenna, C. F.: Hardness of I'lasters and Cements, and a simple Chronographic Apparatus for Recording sot. J. Ind. and Eng. Chem., 4, 110. 1912.

61. Meade, Richard K.: Portland Cement. Faston, 1906.

62. — : The Influence of Fine Grinding upon the Physical Properties of Portland Cement. Cement Age, 7, 161. 1905.

63. — : The Ultimate Composition of Portland Cement. Chem. Eng., 10, 183. 1910 .

64. Michaelis, W. A., Sr., Axd W. A., Jr.: The Hardening Process of Hydraulic Cements. (Paper read before Assn. Ger. Port. Cement Ifrs., Berlin, 1907.) Cem. Eng. News, separate.

65. - : The Hardening of Cement Under Water. (Paper read before Assn. Ger. Port. Cement Mfrs., Berlin, 1909.) Cem. Eng. News, separate.

66. Michaelis, W. A., Sr.: Puzzuolan Mortar's in Sea Water. Tonind. Ztg., 33, 1308.1909.

67. Montemartixt, C.: 'The Hưdration of Cements. L'Industria Chimica, 7, 169.1908 .

68. Newberry, S. B. : Cement for sea Water Construction. Cement Age, 9, 38, 1907 .

69. Newberry, S. B. And W. IB. : Constitution of IIydraulic Cements. J. Soc. Chem. Ind., 16, 887.1897.

70. O'Hara. J. M. : Action of Sea Water on Portland Cement. Cem. Eng. News, 22, 288. 1910.

71. Peterson, P. M. : Determination of the Finest Powder in Portland Cement. Tonind. Ztg., 33, 1687. 1909.

72. Pierce, G.: Destructive Action of Alkali upon Cement. Mining Sci., 63, 130. 1911.

73. Plumb, R. A.: Waterproofing Concrete. Canadian Cement and Conc. Rev.. 4, 91 .

74. Pornson, L.: Studies of the Chemical Influence of Sea Water upon Portland Cement. Ciment. Nos. 6, 7. 1910.

75. Potrer, C. J.: Chemical Changes in Portland Cement concrete. and the Artion of Sea Water thereon. Jour. Soc. Chem. Ind., 28, 6. 1909.

76. Poulsex, A.: Iong Time Concrete Tests in Sea Water. Fng. News. 64, 3. 1910 .

77. Progress Report of the Joint Committee on Concrete and Reinforced Concrete of the American society for Testing Materials. : Proceedings, 1909. 
78. READ, E. J.: The Crystalline Products of the Hardening of Portland Cement. J. Soc. Chem. Ind., 29, 735. 1910. (Discussion by Blount.)

79. Reiblixg Axd Reyes: Physical and Chemical Properties of Portland Cement, III. Phillip. Jour. Sci., 6, 207. 1910.

80. Richardsox, Cirfford: Portland Cement from a Physico-chemical standpoint. Atlantic City, June, 1904. Also, Eng. News, Aug. 11, 1904, Jan. ఇ6, 1905, Cement 1904-1905, 5, 3, et seq.

81. Rohax, W. D.: The Effect of Sea Water, Alkali Water, and Sewage on I'ortland Cement. Eng. Cont., 24, 52. 1905.

82. Romland, I'. The Weathering of Stones and Mortar's. Keits. Chem. Ind. Kolloide, 8, 48. 1911.

83. - Influence of Electrolytes on the Setting Time of Cement. Zeits. Angew. Cliemie, 16, 622, 1903. Stahl u. kisen, 28, 18151908.

84. - Causes for the Changes in speed of II Chem. Ind. Kolloide, 8, 251. 1911.

85. SABIx, L. C.: Cement and Concrete. MeGraw, 1905.

86. SAger AND Craner: The Hardening of Previously set Cement. Tonind. Ztg., 32, 1746. 1908.

87. Sснотт, O.: American Portland Cement Concrete in Sea Water. Chem. Ztg.. 35, 256. 1911.

88. Shepherd axd RaNkix: Preliminary Report on the Ternary System $\mathrm{CaO}-\mathrm{Al}_{2} \mathrm{O}_{3}-\mathrm{SiO}_{2}$. Jour. Ind. and Eng. Chem., 3, 211. 1911.

89. Slichter, C. S.: Theoretical Investigation of the Motion of Ground Water. 19th Ann. Report, U. S. Geol. Surv., pt. 2, 1899.

90. Smitil, A. Enskixe: Some Old Cement Tests. Cone. Eng., 4, 124. 1909.

91. Society Scand. Portland Cement Mfrs.: Sea Water Tests of Portland Cements. Cement Age, 10, 184. 1908.

92. Spackinax. H. S. : Relation of Lime Content of Cement to Durability of Concrete. Concrete, 11, 52. 1911.

93. Spackianx axd Lesley: The Hydraulic Properties of Reground Cement. Cement Age, 10, 1. 1908.

94. Spaldixg, F. P.: Hydraulic Cement. Wiley, 1906.

95. Sterx, E. : The Setting and Hardening of Cement. Mt. Kgl. Materialpruf, 28, 173.1910.

96. Stewardsox, C. W. : The Effect of Alkali on Cement. Brick, 33, 102. 1910.

97. Taylor axd Thompson: Concrete, Plain and Reinforced. Wiley, 1905.

98. Thatcher, E.: 'The Effect of Sea Water upon Portland Cement, Mortar' and Concrete, and upon Steel Embedded Therein. Proc. Am. Soc. C. E.. $34,(2) .1908$.

99. Thoxas, 1.: Colloidal Cement Waterproofing. Cement Age, 11, 158. 1909. 100. Thompsox, G. W.: The Classification of Fine Particles According to Size. Proc. Am. Soc. 'Test. Mat., 10, 601. 1910.

101. Törлевонм (quoted in 80 ) : The Petrography of Portland Cement. Kong. Int. Verb. Material. 1897.

102. Tuttle. M. C. : Decomposition of Concrete in Sea Water. Fing. News, 60, 341.1908.

103. Txger. C. (Tr. by Michatus) : Fused I'ortland rement. Cement Eng. News, 22, 192. 1910. 
104. Van Hise, C. R.: A Treatise on Metamorphism. U. S. Geol. Surv., Monograph 47. 1904.

105. Walling, W. A. B.: Some Notes on the Setting of Cement. Chem. News, 104, 54. 1911.

106. Weston, R. S.: Effect of Sewage on Concrete. (Letter.) Eng. Record, 61, 714. 1909.

107. White, A. H.: Disintegration of Fresh Cement Floor Surfaces by the Action of Smoke Gases at Low Temperatures. Pr. Am. Soc. Test. Materials, 9, 530. 1909.

108. White, A. H.: Destruction of Cement Mortars and Concrete through Expansion and Contraction. Proc. Am. Soc. Test. Mat., 11, 531. 1911.

109. Wig, R. J.: The Effect of High Pressure Steam on the Crushing Strength of Portland Cement Mortar and Concrete. Proc. Am. Soc. Test. Mat., 11, 580. 1911.

110. Williams, I. A.: Influence of Fine Grinding upon the Physical Properties of Portland Cement. Trans. Am. Cer. Soc., 10, 244. 1908.

111. Withey, M. O.: A Survey of the Concrete Aggregates of Wisconsin. Concrete, 12, 55. 1912.

112. Wormser, D. : Changes in the Strength of Portland Cement. Cement Ige, 9, 254. 1907 . 


\section{PUBLICATIONS}

OF THE

\section{NEW YORK ACADEMY OF SCIENCES}

(Lyceum of Natural History, 1817-1876)

The publications of the Academy consist of two series, viz.:

(1) The Annals (octavo series), established in 1823, contain the scientific contributions and reports of researches, together with the records of meetings and similar matter.

A volume of the Annals coincides in general with the calendar year and is sold at the uniform price of three dollars per volume. The articles composing the volume are printed separately, each in its own cover, and are distributed in bundles on an average of three per year. The price of the separate articles depends upon their length and the number of illustrations, and may be learned upon application to the Librarian of the Academy. The author receives his separates as soon as his paper has been printed, the date of issue appearing above the title of each paper.

(2) The Memoirs (quarto series), established in 1895, are issued at irregular intervals. It is intended that each volume shall be devoted to monographs relating to some particular department of Science. Volume I is devoted to Astronomical Memoirs, Volume II to Zoölogical Memoirs, etc. The price is one dollar per part as issued.

All publications are sent free to Fellows and Active Members. The Annals are sent to Honorary and Corresponding Members desiring them.

Subscriptions and inquiries concerning current and back numbers of any of the publications of the Academy should be addressed to

\section{The Librarian,}

New York A'cademy' of Sciences, care of

American Museum of Natural History, New York, N. Y. 



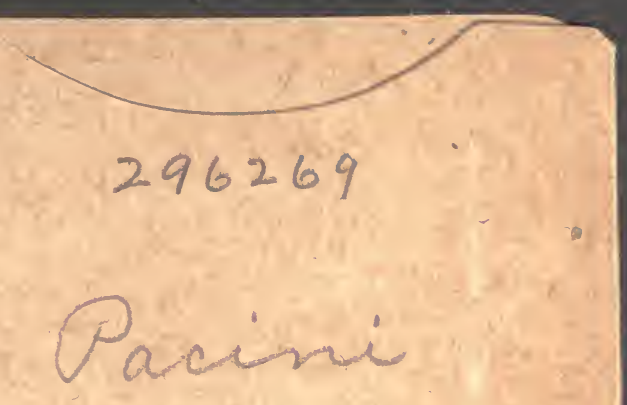

UNIVERSITY OF CALIFORNIA LIBRARY 
